WATER-QUALITY ASSESSMENT OF PERUQUE CREEK, ST. CHARLES COUNTY, MISSOURI, JULY 1983 AND JULY 1984

By Wayne R. Berkas

U.S. GEOLOGICAL SURVEY

Water-Resources Investigations Report 87-4079

Prepared in cooperation with the

MISSOURI DEPARTMENT OF NATURAL RESOURCES,

DIVISION OF ENVIRONMENTAL QUALITY

Rolla, Missouri

1987 


\section{DEPARTMENT OF THE INTERIOR \\ DONALD PAUL HODEL, Secretary}

U.S. GEOLOGICAL SURVEY

Dallas L. Peck, Director

For additional information write or call:

District Chief

U.S. Geological Survey

1400 Independence Road

Mai1 Stop 200

Rolla, Missouri 65401
Copies of this report can be purchased from:

U.S. Geological Survey Books and Open-File Reports Federal Center, B1dg. 41 Box 25425

Denver, Colorado 80225 


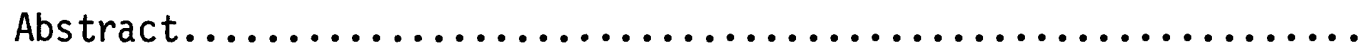

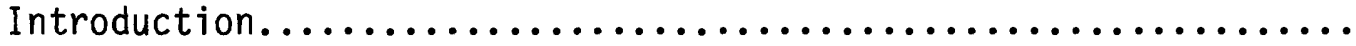

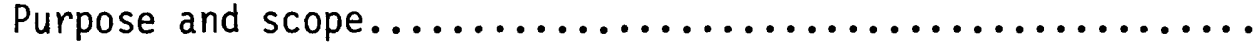

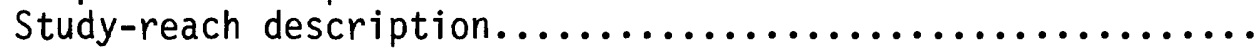

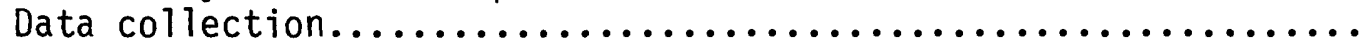

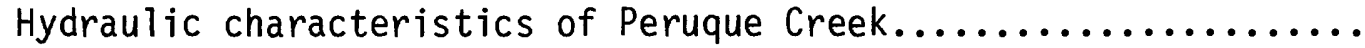

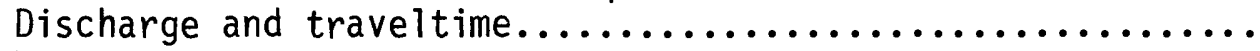

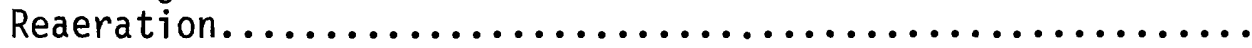

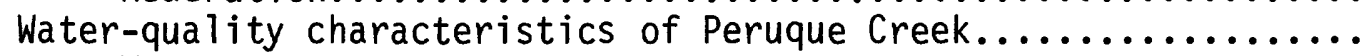

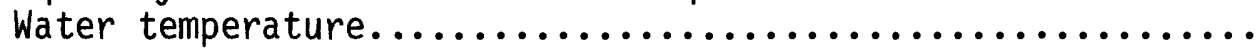

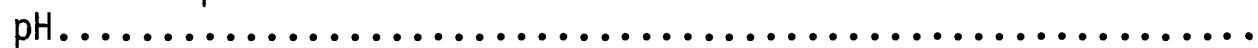

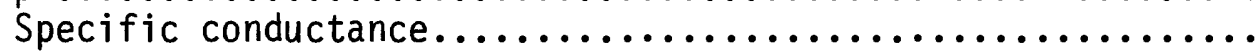

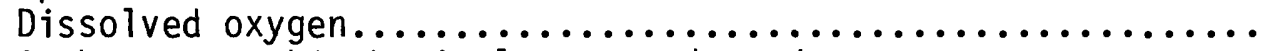

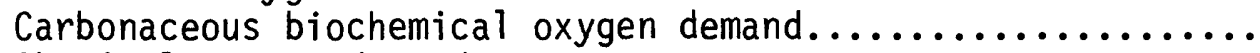

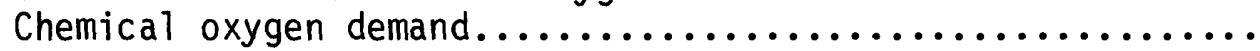

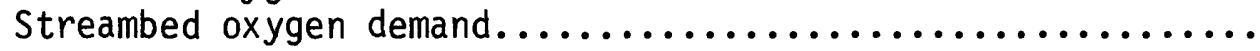

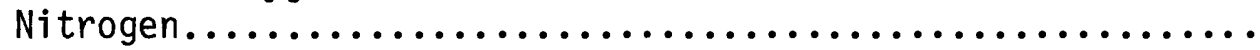

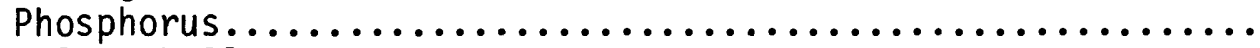

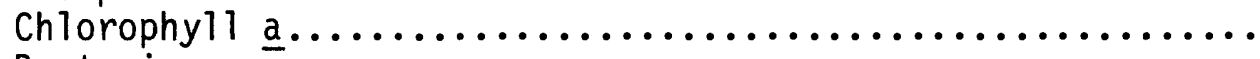

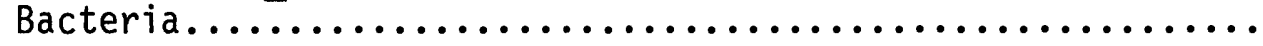

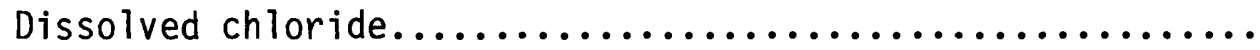

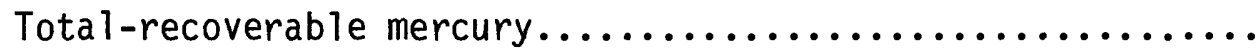

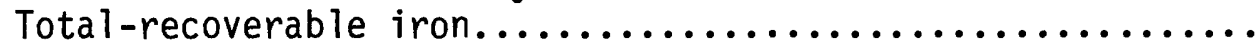

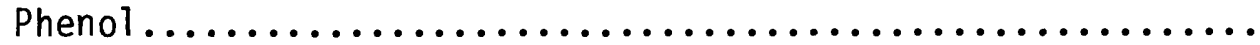

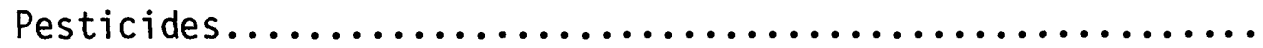

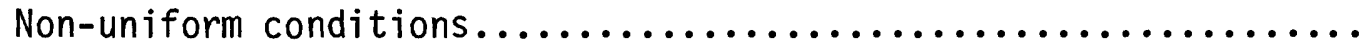

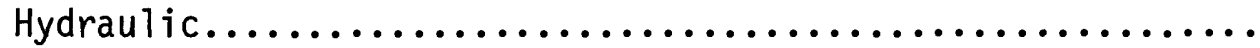

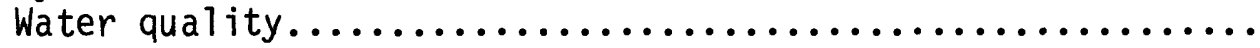

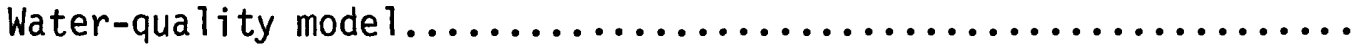

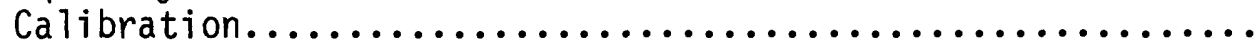

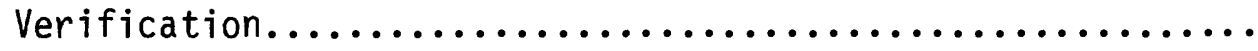

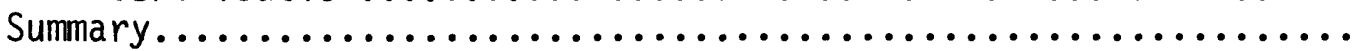

References. 


\section{ILLUSTRATIONS}

Page

Figure 1. Map showing location of sampling sites ............ 4

2. Generalized diagram of one-dimensional flow showing equal velocity through a stream cross section...... 30

3. Generalized diagram of velocity profile in a typical

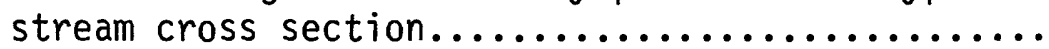

4. Graph showing dye concentrations measured in Peruque Creek, 1.12 river miles downstream from dyeinjection site at the outflow of the Lake St. Louis sewage-disposal ponds.........................

Figures 5.-9. Graphs showing measured and computed concentrations of:

5. Dissolved oxygen, July 18 to $19,1983 \ldots \ldots \ldots \ldots \ldots . . . .37$

6. Total ammonia, July 18 to $19,1983 . . . . . . . . . . . . . .38$

7. Dissolved oxygen, July 9 to $10,1984 . \ldots \ldots \ldots \ldots . . . .639$

8. Five-day carbonaceous biochemical oxygen demand,

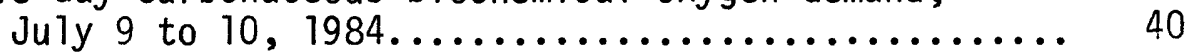

9. Total ammonia, July 9 to $10,1984 \ldots . . \ldots \ldots \ldots . . . .64$ 


\section{TABLES}

Page

Table 1. Discharge, estimated average velocity, and estimated traveltime, July 19, 1983, and July 10, 1984........

2. Comparison of reaeration coefficients calculated from the modified-tracer technique and from empirical

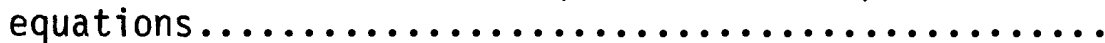

3. Error analys is of predicted reaeration coefficients....

4. Estimated reaeration coefficients between each waterquality sampling site, July 1983 and July 1984......

5. Water-quality data, July 18 to 19, 1983, and July 9

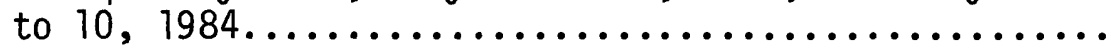

6. Computations of nitrogen loads at selected sampling sites, July 18 to 19,1983 , and July 9 to $10,1984 .$.

7. Decay-rate and reaction-rate constants determined in

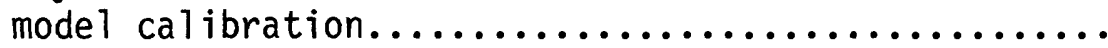

8. Water-quality data input at the headwater and pointsource locations used in model calibration and verification. 


\section{CONVERSION FACTORS}

Inch-pound units in this report may be expressed as metric units using the following conversion table:

To convert inch-pound unit

foot

cubic foot per second

mile

foot per foot

foot per mile

foot per second
Multiply by

0.3048

0.02832

1.609

1.0

0.1894

0.3048
To obtain metric unit

meter

cubic meter per second

kilometer

meter per meter

meter per kilometer

meter per second

Temperature in degrees Celsius $\left({ }^{\circ} \mathrm{C}\right)$ can be converted to degrees Fahrenheit $\left({ }^{\circ} \mathrm{F}\right)$ by using the following equation: ${ }^{\circ} \mathrm{F}=9 / 5{ }^{\circ} \mathrm{C}+32$. 


\title{
WATER-QUALITY ASSESSMENT OF PERUQUE CREEK, ST. CHARLES COUNTY, MISSOURI, JULY 1983 AND JULY 1984
}

\author{
By Wayne R. Berkas
}

\begin{abstract}
Physical, chemical, and biological data were collected along the downstream 24.1-river-mile reach of Peruque Creek from July 18 to 19, 1983, and July 9 to 10, 1984, and were used to characterize the water-quality conditions in the creek. Wastewater sources discharge into the creek at the Lake St. Louis sewage-disposal ponds and at the O'Fallon wastewater-treatment facility. The effluent from the sewage-disposal ponds did not have a substantial effect on water quality downstream. The discharge from the O'Fallon wastewater-treatment facility caused the Missouri un-ionized ammonia water-quality standard of 0.1 milligram per liter as nitrogen to be exceeded downstream from the outflow, and caused all dissolved-oxygen concentrations measured downstream from the outflow to be less than the Missouri dissolved-oxygen standard of 5.0 milligrams per liter.

Attempts were made to calibrate and verify the QUAL-II/SEMCOG version water-quality model. The model could not be adequately calibrated or verified because of slow velocities; long, deep pools; inadequate mixing characteristics; and also the non-uniform quantity and quality of effluent discharged from the O'Fallon wastewater-treatment facility. Thus, the assumptions of onedimensional flow and steady-state conditions necessary for the model were not valid. The attempt to calibrate and verify the model indicated that during low-flow conditions the waste-load assimilative capacity of the downstream 17.9 river miles of Peruque Creek was limited.
\end{abstract}




\section{INTRODUCTION}

The development and implementation of wastewater-treatment and stream water-quality management plans were mandated by Public Law 92-500, Federal Water Pollution Control Act Amendments of 1972. To fulfill a requirement of this law, the Missouri Department of Natural Resources (1976) developed a water-quality management plan in accordance with Section 303e of Public Law 92-500. In this plan, Peruque Creek downstream from Lake St. Louis was identified as a water-quality limited stream, which requires wastewater-treatment facilities to use advanced levels of treatment to protect stream quality. Small dissolvedoxygen concentrations and large fecal-coliform-bacteria populations were cited as conditions caused by multiple wastewater discharges in the basin.

In accordance with Section 208 of Public Law 92-500, area-wide plans were developed for selected metropolitan areas (East-West Gateway Coordinating Council and others, 1977). For the Peruque Creek area, this plan included a recommendation that all wastewater discharges in the area be consolidated into a regional wastewater-treatment facility. The recommendation was later modified by the Missouri Clean Water Commission to allow for subregional wastewatertreatment facilities that would have the same effect on the environment as a single regional wastewater-treatment facility.

A requirement of Public Law 92-500, Section 201, is the development of a plan that would identify the future wastewater-management needs of municipalities. Sverdrup and Parcel and Associates (1984) developed a plan in which specific wastewater alternatives were determined for the Peruque Creek basin downstream from Lake St. Louis. An increase in population in the basin is anticipated, and expansion of existing wastewater-treatment facilities and construction of new wastewater-treatment facilities are planned.

The Missouri Department of Natural Resources (1984) classified Peruque Creek as a perennial stream from Lake St. Louis to the Mississippi River. The water-quality standards for perennial streams require that contaminants shall not cause or contribute to the violation of maximum specific limitations for designated use of the water. Exceptions are granted by the Missouri Clean Water Commission when flow in perennial streams is less than the average minimum flow for 7 consecutive days that has a recurrence interval of 10 years (7-day, $Q_{10}$ ) and may be granted when the effluent constitutes more than one-half of the streamflow. The Missouri Clean Water Commission did not grant any exception in Peruque Creek before this study (1986). The designated uses for this reach of Peruque Creek are livestock and wildlife watering, boating, and protection of aquatic life.

\section{Purpose and Scope}

This study, in cooperation with the Missouri Department of Natural Resources, Division of Environmental Quality, was made as a partial fulfillment of the requirements of Public Law 92-500. The primary objectives were to collect hydraulic and water-quality data in the 24.1-river-mile reach of Peruque Creek downstream from Lake St. Louis, and to compare the water-quality data to the Missouri water-quality standards. The study also was to evaluate wastewater-management alternatives by simulating water-quality conditions in Peruque Creek using a water-quality model. Because wastewater effluent can greatly influence the dissolved-oxygen concentrations in receiving streams, dissolved-oxygen concentrations in Peruque Creek were of primary concern. 
This report presents results of data collected during two 24-hour periods. The data from both periods were used to indentify any violations of the Missouri water-quality standards. The first set of data were used to calibrate the QUAL-II/SEMCOG water-quality model (Roesner and others, 1981), and the second set of data were used to verify the model. The model could not be completely calibrated or verified for reasons given in the report.

\section{Study-Reach Description}

Peruque Creek is a northwest flowing tributary of the Mississippi River in St. Charles County, Missouri. The study reach is the 24.1 river miles downstream from Lake St. Louis to the Mississippi River (fig. 1). Flow in the study reach is sustained by outflow from Lake St. Louis through an open spillway and a culvert spillway. During low-flow conditions, water flows through the culvert spillway at about 1.0 cubic foot per second.

Upstream from the 0'Fallon wastewater-treatment facility, Peruque Creek flows through an area of steep upland to slightly sloping topography. The soils in this area are deep, well drained to moderately well drained, loamy, and overlain by loess on the ridge tops and side slopes (Allgood and Persinger, 1979). This area predominately is urban with some row-crop farming near the creek. The creek is characterized by a deep U-shaped channel with silt and clay sides, and sand and gravel bottom. The channel slope averages 0.000947 foot per foot ( 5 feet per mile). During low-flow conditions, the creek is characterized by long shallow pools with occasional short riffles. Few piles of uprooted trees and other debris were observed in the channel. Some attached aquatic vegetation was observed in the channel, especially downstream from the Lake St. Louis sewage-disposal ponds. Turbidity was not measured but was observed to be relatively substantial. The creek is well shaded by trees downstream from site 3.

Downstream from the O'Fallon wastewater-treatment facility, Peruque Creek flows through the flood plain of the Mississippi River. The soils in this area are moderately well drained to poorly drained loam and clay (Allgood and Persinger, 1979). This area predominately is row-crop agriculture. Some of the fields are designed to be flooded for duck and goose hunting. The creek is characterized by a deep U-shaped channel with silt and clay comprising the sides and bottom. The channel slope averages 0.000203 foot per foot ( 1 foot per mile). During low-flow conditions, the creek is characterized by a long, deep pool with slow-moving water. Piles of trees and other debris that have washed down the creek are present at many places in the channel. These debris piles did not seem to restrict the flow during data collection. Floating aquatic vegetation was observed to cover large areas of the surface of the creek, particularly those areas sheltered from the wind. Turbidity was observed to be relatively substantial during data collection. This reach of Peruque Creek is well-shaded by trees.

Population in St. Charles County increased from 92,954 in 1970 to 144,107 in 1980 (U.S. Department of Commerce, 1983). The population of 0'Fallon increased from 7,018 in 1970 to 8,677 in 1980. The town of Lake St. Louis did not exist in 1970, but in 1980 the population was 3,843 . 


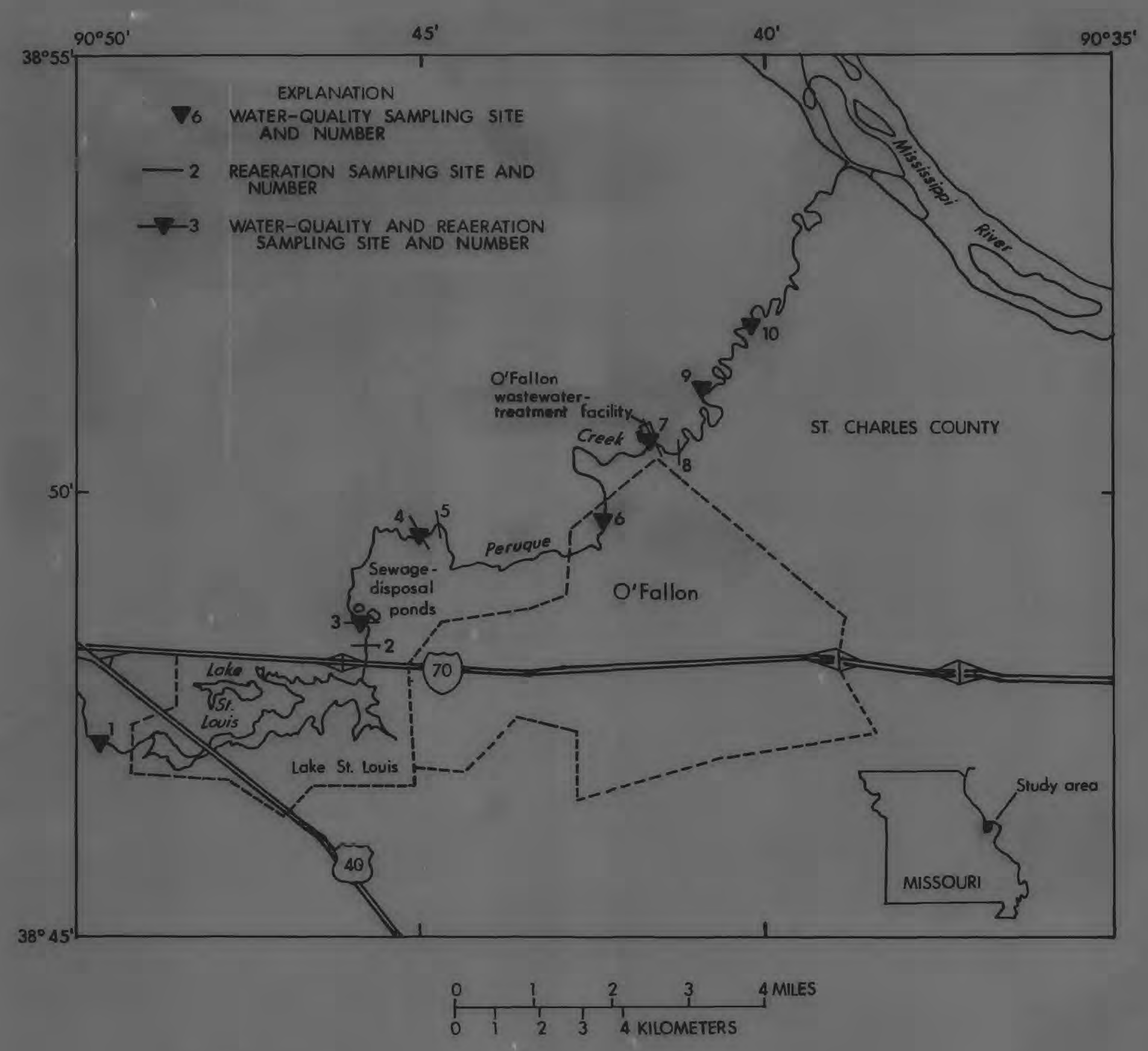

Figure 1.--Location of sampling sites. 
Wastewater discharges into Peruque Creek from two sources (fig. 1). Wastewater from Lake St. Louis enters Peruque Creek at the sewage-disposal ponds, 17.8 river miles upstream from the Mississippi River. These ponds provide the only wastewater treatment for the town of Lake St. Louis. Wastewater from 0'Fallon enters Peruque Creek from the 0'Fallon wastewatertreatment facility, 9.2 river miles upstream from the Mississippi River. The o'Fallon facility provides secondary treatment with a modified active-sludge process.

Peruque Creek from the O'Fallon wastewater-treatment facility to the Mississippi River is classified by the Missouri Department of Natural Resources (1984) as a backwater area of the Mississippi River. This study was made during low-flow conditions and backwater from the Mississippi River was observed as far upstream as site 10 (fig. 1).

\section{DATA COLLECTION}

Stream discharge, in cubic feet per second, and channel geometry (width and depth), in feet, used to determine the hydraulic characteristics of and reaeration coefficients for Peruque Creek were measured on July 10, 1984, at sites $1,3,4,6,7,9$, and 10 , and at the outflows of the Lake St. Louis sewage-disposal ponds and the 0'Fallon wastewater-treatment facility. Samples for the determination of streambed oxygen demand, in grams per square meter, also were collected on July 19, 1983, at sites $3,4,6,7$, and 10, and at sites 250 feet downstream from the outfalls of the Lake St. Louis sewage-disposal ponds and the 0'Fallon wastewater-treatment facility.

Water samples used to determine the quality of Peruque Creek were collected during each 24-hour period in July 1983 and July 1984 at sites 1, 3, 4, 6, 7, 9, and 10, and at the outfalls of the Lake St. Louis sewage-disposal ponds and the o'Fallon wastewater-treatment facility. Physical properties of the samples were measured at the sampling sites by U.S. Geological Survey personnel. Analysis of the samples was done by the Missouri Department of Natural Resources, Division of Envirnomental Quality, using procedures described by the American Public Health Association and others (1985).

Physical properties were measured every 4 hours, except at the Lake St. Louis sewage-disposal ponds where they were measured three times during each of the data-collection periods. The following properties were measured:

1. Water temperature, in degrees Celsius.

2. $\mathrm{pH}$, in standard units.

3. Specific conductance, in microsiemens per centimeter at $25{ }^{\circ} \mathrm{Celsius.}$

4. Dissolved oxygen, in milligrams per liter.

Each of the samples for which physical properties were determined was analyzed for:

1. 5-day carbonaceous biochemical oxygen demand, in milligrams per liter.

2. Total ammonia, in milligrams per liter as nitrogen.

3. Total nitrite plus nitrate, in milligrams per liter as nitrogen.

4. Dissolved orthophosphate, in milligrams per liter as phosphorus. 
In addition, one of these samples were analyzed for:

1. Chemical oxygen demand, in milligrams per liter (only samples collected in 1983 ).

2. Chlorophyll a, in micrograms per liter.

3. Fecal-coliform, in colonies per 100 milliliters.

4. Fecal-streptococci, in colonies per 100 milliliters.

5. Dissolved chloride, in milligrams per liter.

6. Total-recoverable mercury, in micrograms per liter. (only samples collected in 1984)

7. Total-recoverable iron, in micrograms per liter.

8. Phenol, in micrograms per liter.

9. Selected pesticides (dieldrin, chlordane, toxaphene, and lindane), in micrograms per liter.

\section{HYDRAULIC CHARACTERISTICS OF PERUQUE CREEK}

The hydraulic characteristics measured or determined in this study were stream discharge, traveltime, and reaeration. These data helped define the physical characteristics of Peruque Creek.

\section{Discharge and Traveltime}

During low-flow conditions, the discharge in Peruque Creek is regulated by water released from the Lake St. Louis Dam. Water released from the dam enters Peruque Creek by a culvert spillway. Because the culvert spillway cannot be closed, flow throudg it will maintain a discharge of about 1.0 cubic foot per second, even during extremely dry periods.

The discharge in Peruque Creek is augmented by wastewater effluent from the Lake St. Louis sewage-disposal ponds and the 0'Fallon wastewater-treatment facility. Because the sewage entering the ponds must travel through two large ponds, any variability in sewage inflow is dampened and outflow from the Lake St. Louis sewage-disposal ponds is fairly constant. The measured discharge from the ponds during the 1983 sampling period was similar to the measured discharge during the 1984 sampling period (table 1), which indicated that the volume of sewage treated by the sewage-disposal ponds changed little between the two sampling periods.

Because Peruque Creek is augmented by sewage-effluent outflow, a significant characteristic of the discharge in Peruque Creek is the quantity of dilution it would provide for the effluent from the Lake St. Louis sewagedisposal ponds. During the 1983 sampling period, the flow at site 3, which is only 500 feet upstream from the outflow of the sewage-disposal ponds, was 1.12 cubic feet per second and the flow from the sewage-disposal ponds was 0.81 cubic foot per second, which indicated the wastewater outflow contributed 42 percent of the flow in Peruque Creek downstream from the ponds. During the 1984 sampling period, the flow at site 3 was 1.95 cubic feet per second and the flow from the sewage-disposal ponds was 0.80 cubic foot per second, which indicated that the wastewater contributed 29 percent of the flow in Peruque Creek downstream from the ponds. The larger diluting capacity during the 1984 sampling period was because of the larger discharge in Peruque Creek. 
Table 1.--Discharge, estimated average velocity, and estimated traveltime, July 19, 1983, and July 10, 1984

[--, data not collected or not computed]

\begin{tabular}{|c|c|c|c|c|c|c|}
\hline $\begin{array}{l}\text { Sampling } \\
\text { site } \\
\text { number } \\
\text { or } \\
\text { location } \\
\text { (fig. 1) }\end{array}$ & $\begin{array}{l}\text { River } \\
\text { miles }\end{array}$ & $\begin{array}{l}\text { Distance } \\
\text { downstream } \\
\text { from } \\
\text { upstream } \\
\text { end of } \\
\text { subreach, } \\
\text { in river } \\
\text { miles }\end{array}$ & Date & $\begin{array}{l}\text { Discharge, } \\
\text { in cubic } \\
\text { feet per } \\
\text { second }\end{array}$ & $\begin{array}{l}\text { Es timated } \\
\text { average } \\
\text { velocity } \\
\text { in } \\
\text { subreach, } \\
\text { in feet } \\
\text { per second }\end{array}$ & $\begin{array}{c}\text { Estimated } \\
\text { traveltime } \\
\text { in } \\
\text { subreach, } \\
\text { in days }\end{array}$ \\
\hline 1 & 24.1 & -- & $\begin{array}{l}7-19-83 \\
7-10-84\end{array}$ & $\begin{array}{r}0.80 \\
.70\end{array}$ & -- & -- \\
\hline 3 & 17.9 & -- & $\begin{array}{l}7-19-83 \\
7-10-84\end{array}$ & $\begin{array}{l}1.12 \\
1.95\end{array}$ & -- & -- \\
\hline $\begin{array}{l}\text { Lake St. } \\
\text { Louis } \\
\text { sewage- } \\
\text { disposal } \\
\text { ponds }\end{array}$ & 17.8 & 0.1 & $\begin{array}{l}7-19-83 \\
7-10-84\end{array}$ & $\begin{array}{l}.81 \\
.80\end{array}$ & $\begin{array}{l}-- \\
--\end{array}$ & $\begin{array}{l}-- \\
--\end{array}$ \\
\hline 4 & 15.2 & 2.6 & $\begin{array}{l}7-19-83 \\
7-10-84\end{array}$ & $\begin{array}{l}2.51 \\
2.70\end{array}$ & $\begin{array}{r}0.03 \\
.03\end{array}$ & $\begin{array}{l}5.3 \\
5.3\end{array}$ \\
\hline 6 & 11.9 & 3.3 & $\begin{array}{l}7-19-83 \\
7-10-84\end{array}$ & $\begin{array}{l}3.26 \\
3.31\end{array}$ & $\begin{array}{l}.03 \\
.03\end{array}$ & $\begin{array}{l}6.7 \\
6.7\end{array}$ \\
\hline 7 & 9.2 & 2.7 & $\begin{array}{l}7-19-83 \\
7-10-84\end{array}$ & $\begin{array}{r}3.37 \\
3.43\end{array}$ & $\begin{array}{l}.08 \\
.07\end{array}$ & $\begin{array}{l}2.1 \\
2.4\end{array}$ \\
\hline $\begin{array}{l}\text { 0'Fallon } \\
\text { wastewater } \\
\text { treatment } \\
\text { facility }\end{array}$ & $e^{9.2}$ & -- & $\begin{array}{l}7-19-83 \\
7-10-84\end{array}$ & $b_{3.29}$ & $\begin{array}{l}-- \\
--\end{array}$ & $\begin{array}{l}-- \\
--\end{array}$ \\
\hline 9 & 6.9 & 2.3 & $\begin{array}{l}7-19-83 \\
7-10-84\end{array}$ & $6 . \overline{70}$ & $\begin{array}{l}.07 \\
.06\end{array}$ & $\begin{array}{l}2.0 \\
2.3\end{array}$ \\
\hline 10 & 5.5 & 1.4 & $\begin{array}{l}7-19-83 \\
7-10-84\end{array}$ & $\begin{array}{c}c_{2.89} \\
--\end{array}$ & $\begin{array}{l}.06 \\
.04\end{array}$ & $\begin{array}{l}1.4 \\
2.1\end{array}$ \\
\hline
\end{tabular}

${ }_{b}^{a}$ River miles upstream from the Mississippi River.

Average discharge.

${ }^{C}$ Affected by irrigation pumpage from Peruque Creek. 
The discharge from the O'Fallon wastewater-treatment facility was variable within each sampling period because of the short retention time in the wastewater-treatment process. Unlike the Lake St. Louis sewage-disposal ponds, the O'Fallon wastewater-treatment facility did not incorporate any holding ponds in the treatment process. The diurnal flow fluctuations of the raw sewage entering the treatment plant would not be decreased substantially by the time the effluent left the wastewater-treatment facility. Because of the variability of effluent discharge, numerous measurements of effluent discharge were made during both sampling periods and average discharges were determined (table 1). The average effluent discharge determined during the 1984 sampling period was more than twice the average effluent discharge determined during the 1983 sampling period, which indicates that daily discharges from the wastewatertreatment facility may be substantially different.

As in the case of the Lake St. Louis sewage-disposal ponds, it is helpful to know the degree of dilution that Peruque Creek can provide for the effluent from the 0'Fallon wastewater-treatment facility. During the 1983 sampling period, the discharge at site 7 , which is only 150 feet upstream from the outfall of the wastewater-treatment facility, was 3.37 cubic feet per second and the average discharge from the 0'Fallon treatment facility was 1.34 cubic feet per second, which indicated the effluent contributed 29 percent of the flow in Peruque Creek. During the 1984 sampling period, the discharge at site 7 was 3.43 cubic feet per second and the discharge from the 0'Fallon treatment facility was 3.29 cubic feet per second, which indicated the effluent contributed 49 percent of the flow in Peruque Creek. The smaller diluting capacity during the 1984 sampling period was due to the increased effluent discharge from the wastewater-treatment facility.

Traveltime is the time required for water in a stream to travel downstream from one location to another. Traveltime was determined by using dye-tracing techniques described by Wilson (1968). Rhodamine WT, a fluorescent dye, was injected into Peruque Creek at selected locations. Because the dye is soluble, it moves in a manner similar to water; therefore, measuring the time required for the dye to travel from one point to another also is measuring the time required for the water.

Traveltime and average velocity were estimated between sites 3 and 10 in Peruque Creek for both sampling periods. Estimates were made because the slow velocity of the creek made it extremely difficult to measure traveltime between each water-quality sampling site. Traveltime was measured in a number of subreaches, and these data were used to estimate traveltime and average velocity between each sampling site. The slowest average velocity was estimated between sites 3 and 6 , which indicates that the pool and riffle nature of the creek channel retards the flow during low-flow conditions.

In this study a significant hydraulic characteristic indicated by traveltime is the time required for sewage effluent to travel from the outflow site to near the end of the study reach. During the 1983 sampling period, it was estimated that sewage effluent from the Lake St. Louis sewage-disposal ponds would take 17.5 days to travel the 12.3 river miles to site 10 , and would take 18.8 days during the 1984 sampling period. During the 1983 sampling period it also was estimated that the sewage effluent from the 0'Fallon wastewatertreatment facility would take 3.4 days to travel the 3.7 river miles to site 10 , and 4.4 days during the 1984 sampling period. These traveltimes could have a significant effect on how the water-quality properties and constituents in the wastewater effluent are changed in Peruque Creek. 


\section{Reaeration}

Reaeration is the absorption of oxygen from the atmosphere by the water in the stream. Reaeration is the primary process that replaces the oxygen consumed by oxidizing organic material and ammonia in many streams. The rate of oxygen absorption is proportional to the saturation deficit between the air and the water surface. The reaeration coefficient is the rate constant for the absorption of oxygen from the atmosphere. Knowledge of the reaeration coefficient helps one understand how much oxygen consumption can occur in a stream without depleting the dissolved-oxygen concentration of a stream.

Reaeration coefficients were calculated in Peruque Creek using the modified-tracer technique developed by Rathbun and others (1975). Propane and ethylene were used as tracer gases, and rhodamine-WT dye was used as the dispersion and dilution tracer.

The technique consists of injecting a tracer gas and dye into the stream and measuring the gas and dye concentrations at selected locations downstream. The difference between the total quantity of gas measured at two sampling locations is used to calculate a desorption coefficient of the gas. This desorption coefficient is proportional to the reaeration coefficient.

Several investigators believe that reaeration coefficients are a function of stream velocity and channel geometry (Bennett and Rathbun, 1972; Owens and others, 1964). As discharge changes, the reaeration coefficient also changes. Rathbun (1977) evaluated a number of empirical equations that have been developed to predict reaeration coefficients and determined that the equations gave a considerable range of values for a specific set of hydraulic conditions. Before an empirical equation is chosen to predict the reaeration coefficient in a stream, the results need to be compared to reaeration coefficients calculated in that stream.

Because of the long traveltimes between water-quality sampling sites, reaeration coefficients were calculated for short subreaches in Peruque Creek. These calculated reaeration coefficients were compared to reaeration coefficients estimated by empirical equations. An empirical equation that best estimated reaeration coefficients in Peruque Creek was used to estimate reaeration coefficients between each water-quality sampling site. The following empirical equations were used in the comparison of reaeration coefficients:

Bansal (1973)

Equation

$$
K_{2}=5.26 U^{0.60} D^{-1.40}
$$

Bennett and Rathbun (1972)

$$
\begin{aligned}
& K_{2}=20.2 U^{0.607} D^{-1.689} \\
& K_{2}=106 U^{0.413} D^{-1.408} S^{0.273}
\end{aligned}
$$

Cadwallder and McDonnell (1969)

$$
K_{2}=59.1(32.2 U S)^{0.5} D^{-1.0}
$$


Churchill and others (1962)

$$
\begin{aligned}
& K_{2}=11.6 U^{0.969} D^{-1.673} \\
& K_{2}=3.33 U^{-1.049} D^{-2.262}\left(257.6 D S / U^{2}\right)^{-0.823}
\end{aligned}
$$

Langbein and Durum (1967)

$$
\mathrm{K}_{2}=7.61 \mathrm{UD}^{-1.33}
$$

Negulescu and Rojanski (1969)

$$
\mathrm{K}_{2}=10.9(\mathrm{U} / \mathrm{D})^{0.85}
$$

0 'Connor and Dobbins (1958)

$$
K_{2}=12.96 U^{0.5} D^{-1.5}
$$

Owens and others (1964)

$$
\begin{aligned}
& K_{2}=23.3 U^{0.73} D^{-1.75} \\
& K_{2}=21.7 U^{0.67} D^{-1.85}
\end{aligned}
$$

Padden and Gloyna (1971)

$$
K_{2}=6.86 U^{0.703} D^{-1.054}
$$

where $\mathrm{K}_{2}=$ the reaeration coefficient per day, at $20^{\circ} \mathrm{Celsius,}$ in base e units;

$$
\begin{aligned}
& U=\text { average velocity, in feet per second; } \\
& D=\text { average channel depth, in feet; and } \\
& S=\text { average channel slope, in foot per foot. }
\end{aligned}
$$

Reaeration coefficients calculated using the modified-tracer technique were compared to reaeration coefficient estimated by the 12 empirical equations (table 2). Evaluation to determine the equation that most accurately estimated the reaeration coefficient in Peruque Creek was made by comparing the error of estimate (table 3 ). The error of estimate was computed as follows:

Error of estimate $=$

Value calculated by - Value calculated by empirical equation - modified tracer technique value calculated by modified-tracer technique

The equation that had the smallest average error of estimate was equation 3 (Bennett and Rathbun, 1972). This equation was used to estimate reaeration coefficients between water-quality sampling sites (table 4).

\section{WATER-QUALITY CHARACTERISTICS OF PERUQUE CREEK}

Water-quality characteristics of Peruque Creek were based on data collected at seven sites along Peruque Creek during July 18 to 19,1983 , and July 9 to 10 , 1984. Water-quality properties and constituents are discussed in the following sections, and the data are presented in table 5. 


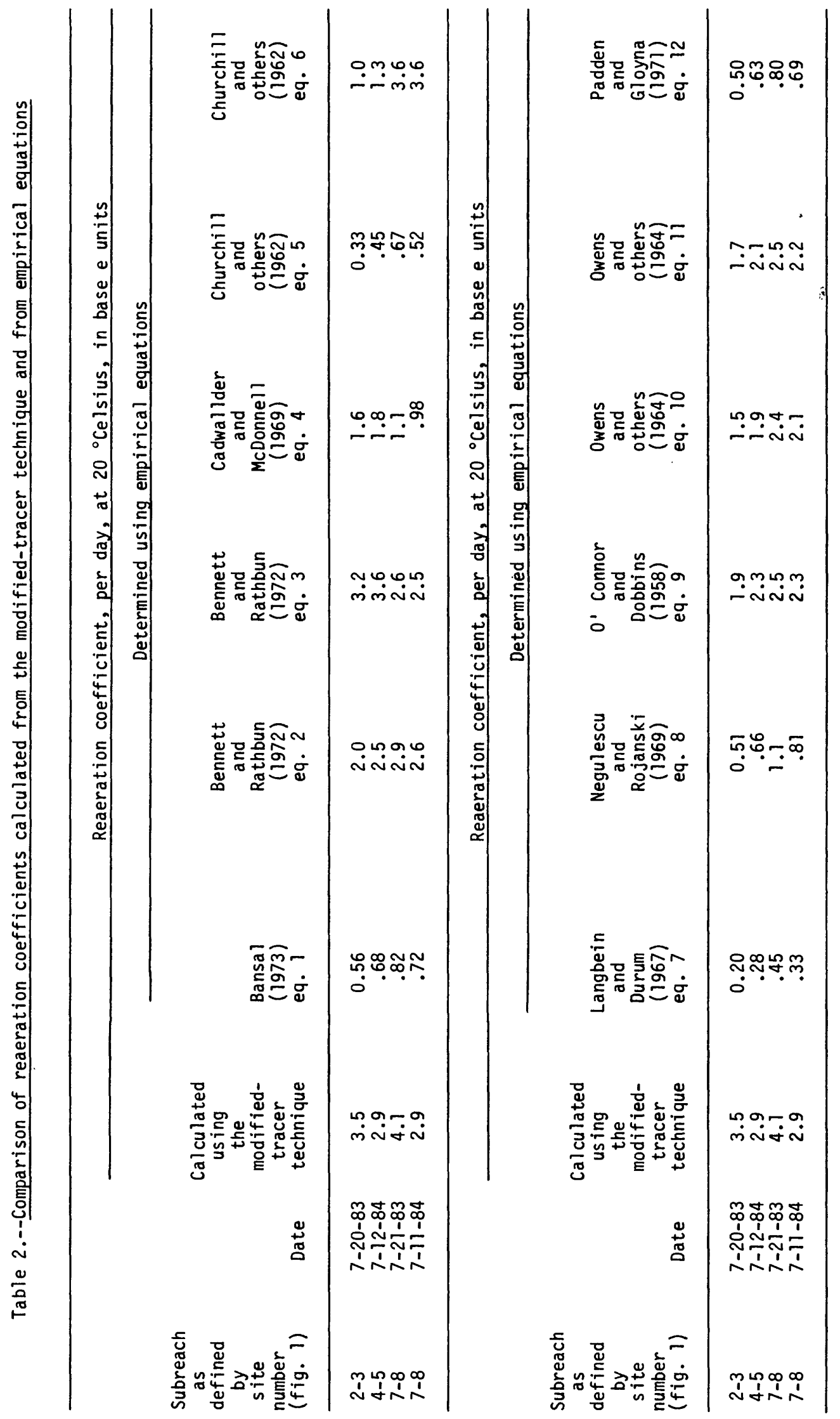


Table 3.--Error analysis of predicted reaeration coefficients

\begin{tabular}{lllll}
\hline $\begin{array}{c}\text { Equation } \\
\text { number }\end{array}$ & \multicolumn{1}{c}{ Author } & $\begin{array}{c}\text { Range of error } \\
\text { of estimate }\end{array}$ & $\begin{array}{c}\text { Average } \\
\text { error of } \\
\text { estimate }\end{array}$ \\
\hline 1 & Bansal (1973) & 0.75 to 0.84 & 0.79 \\
2 & Bennett and Rathbun (1972) & .11 to .42 & .24 \\
3 & Bennett and Rathbun (1972) & .088 to .36 & .20 \\
4 & Cadwal1der and McDonne11 (1969) & .39 to .73 & .58 \\
5 & Churchi11 and others (1962) & .82 to .91 & .86 \\
6 & Churchi11 and others (1962) & .13 to .70 & .90 \\
7 & Langbein and Durum (1967) & .88 to .94 & .77 \\
8 & Negulescu and Rojanski (1969) & .72 to .85 & .31 \\
9 & 0'Connor and Dobbins (1958) & .20 to .44 & .40 \\
10 & Owens and others (1964) & .29 to .57 & .36 \\
11 & Owens and others (1964) & .26 to .50 & .80 \\
12 & Padden and Gloyna (1971) & .76 to .86 & \\
\hline
\end{tabular}


Table 4.--Estimated reaeration coefficients between each water-quality sampling site, July 1983 and July 1984

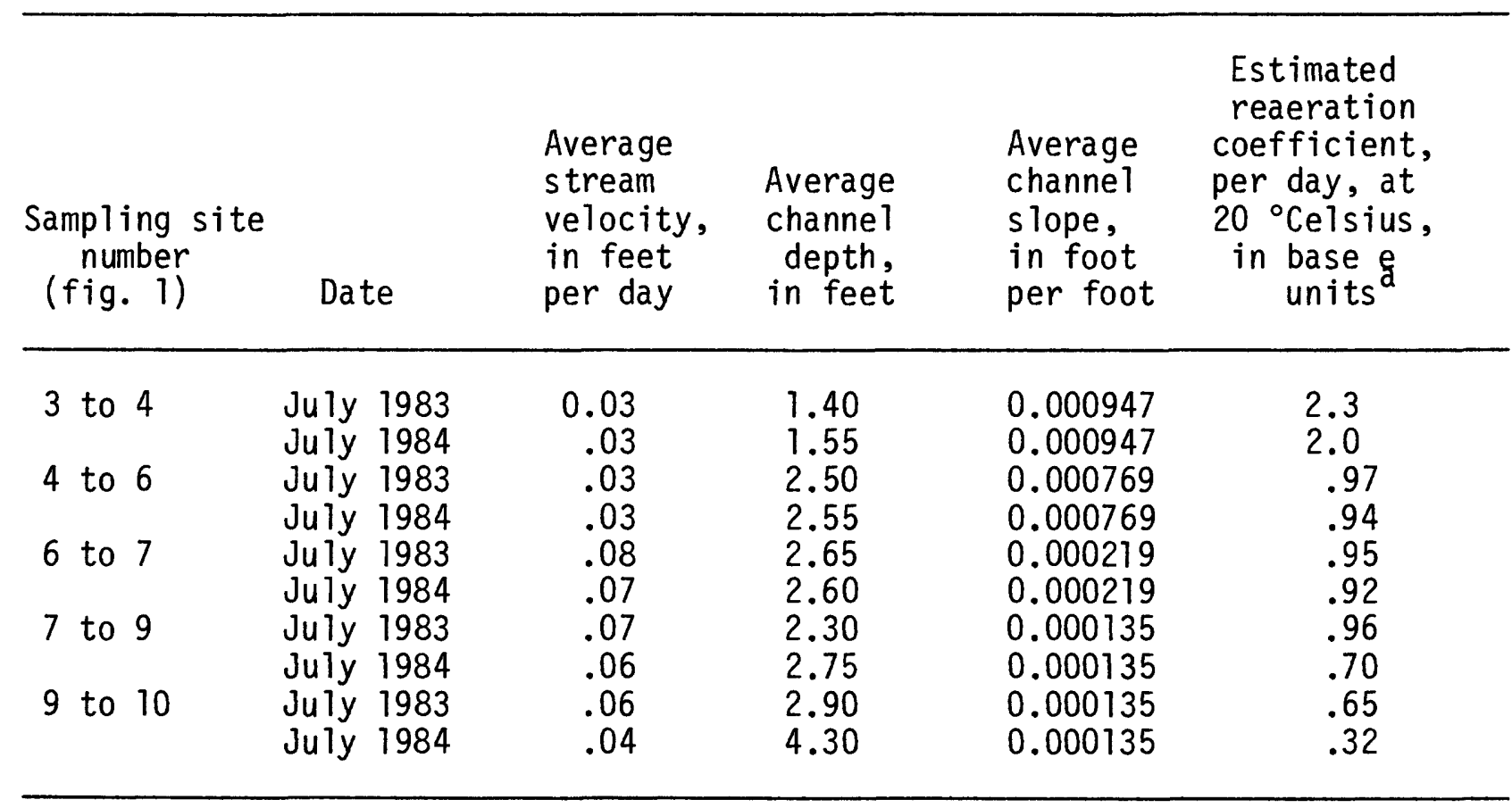

${ }^{a}$ Estimated from equation developed by Bennett and Rathbun (1972) $\begin{aligned} K_{2} & =106 U^{0.413} \mathrm{D}^{-1.408} \mathrm{~S}^{0.273} \\ \text { where } K_{2}^{2}= & \text { the reaeration coefficient, per day, at } 20{ }^{\circ} \mathrm{Celsius,} \text { in base e } \\ & \text { units; }\end{aligned}$

$U=$ the average stream velocity in feet per second;

$D=$ the average channel depth, in feet; and

$S=$ the average channel slope, in foot per foot. 


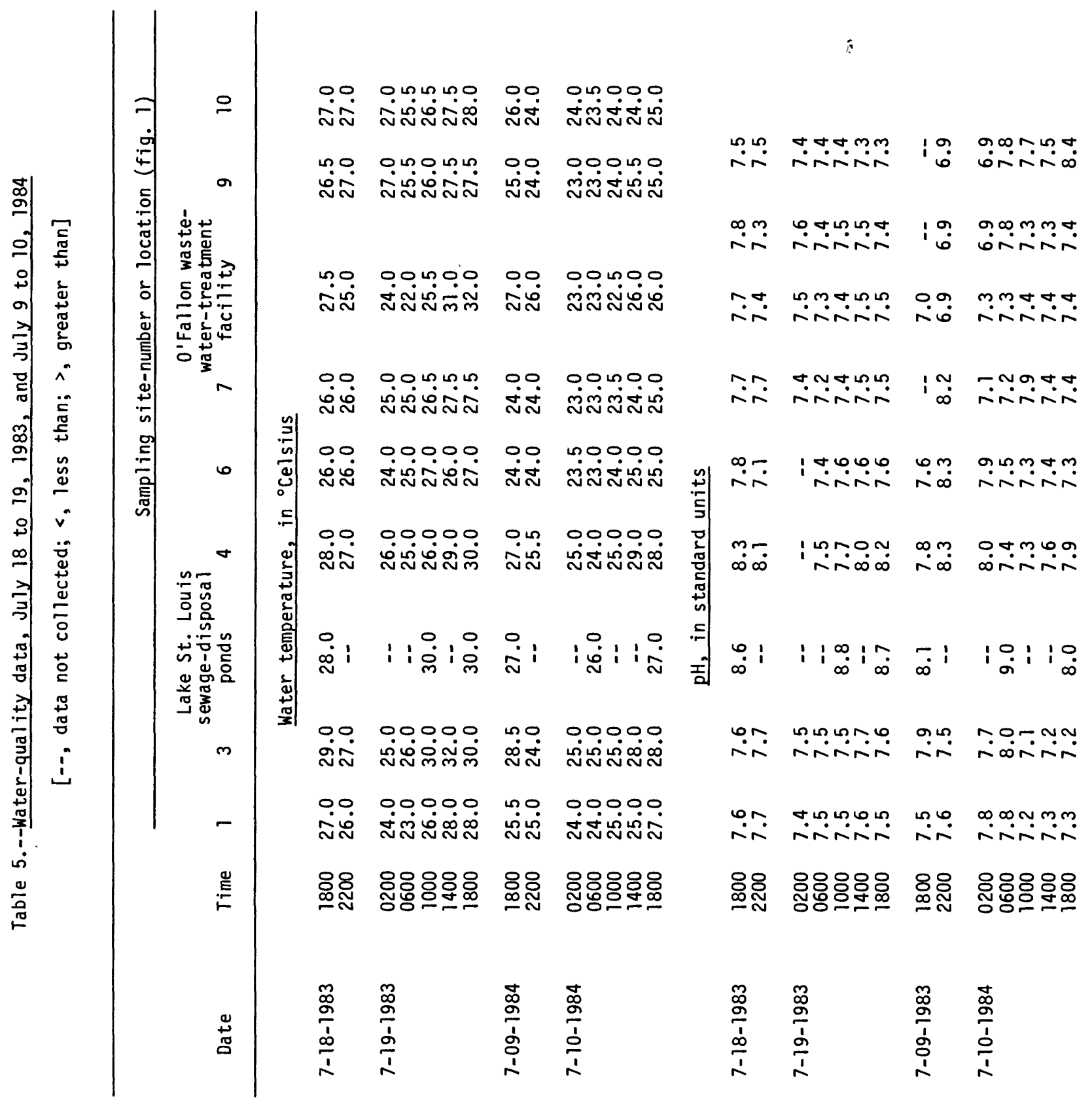




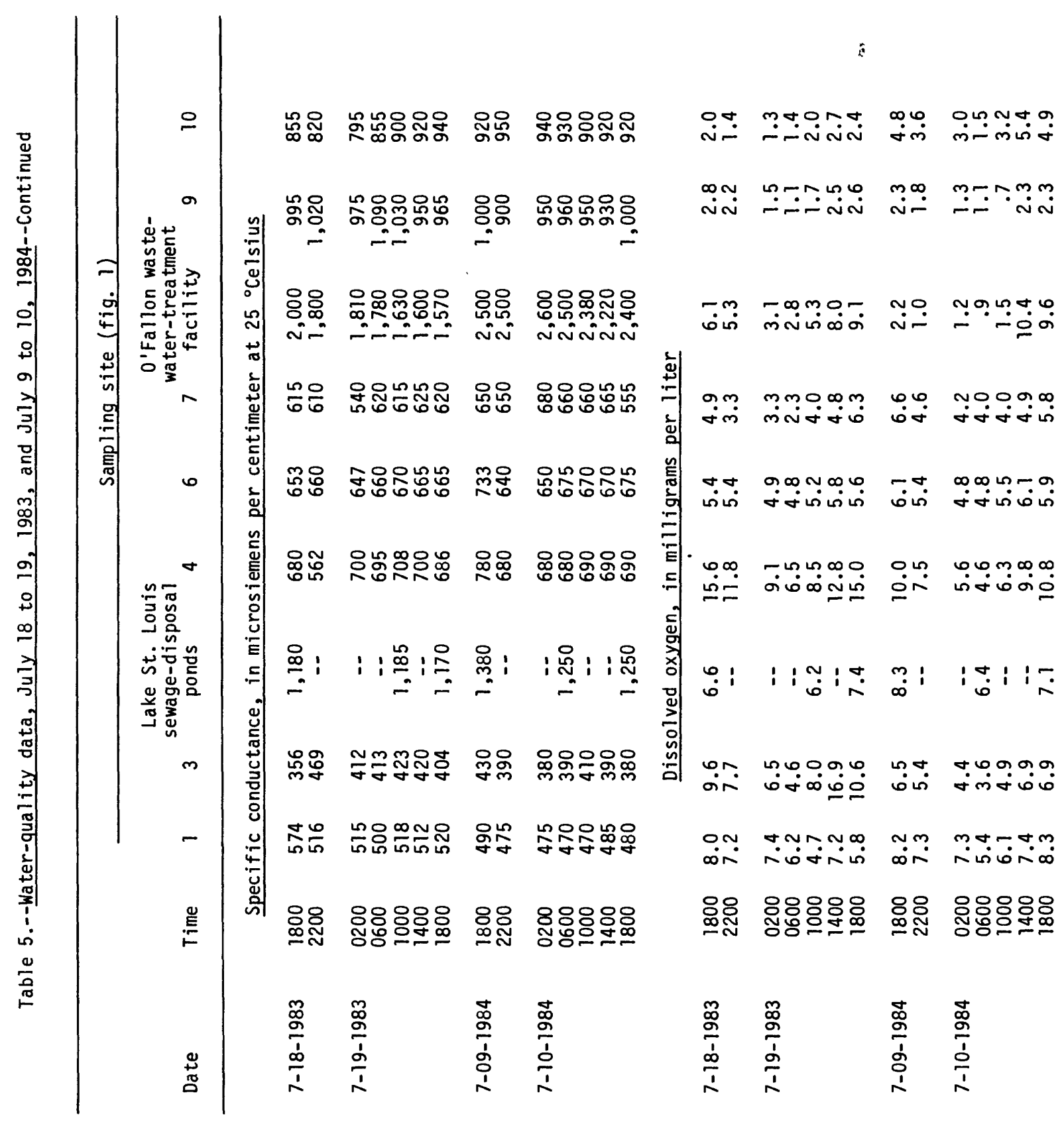




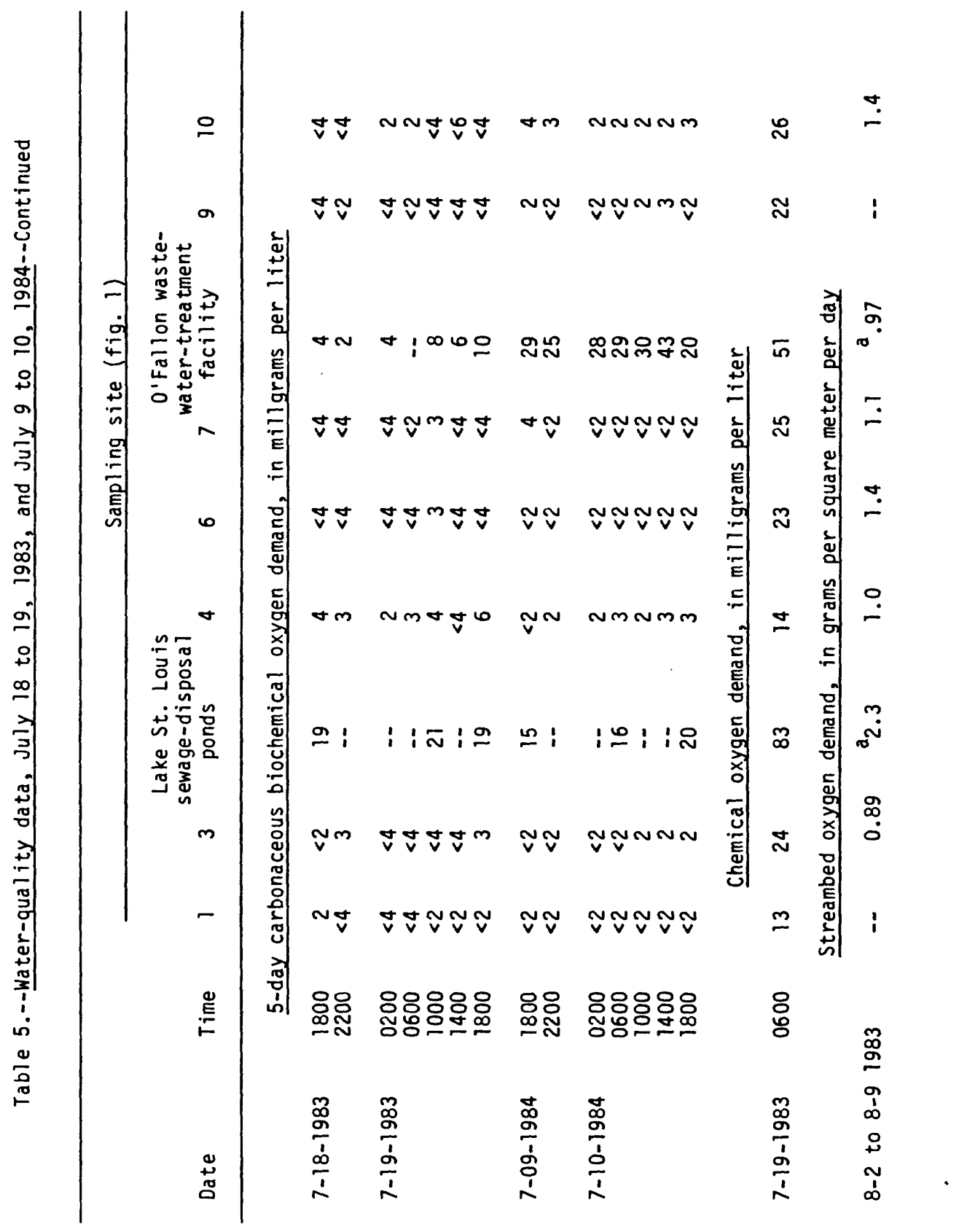




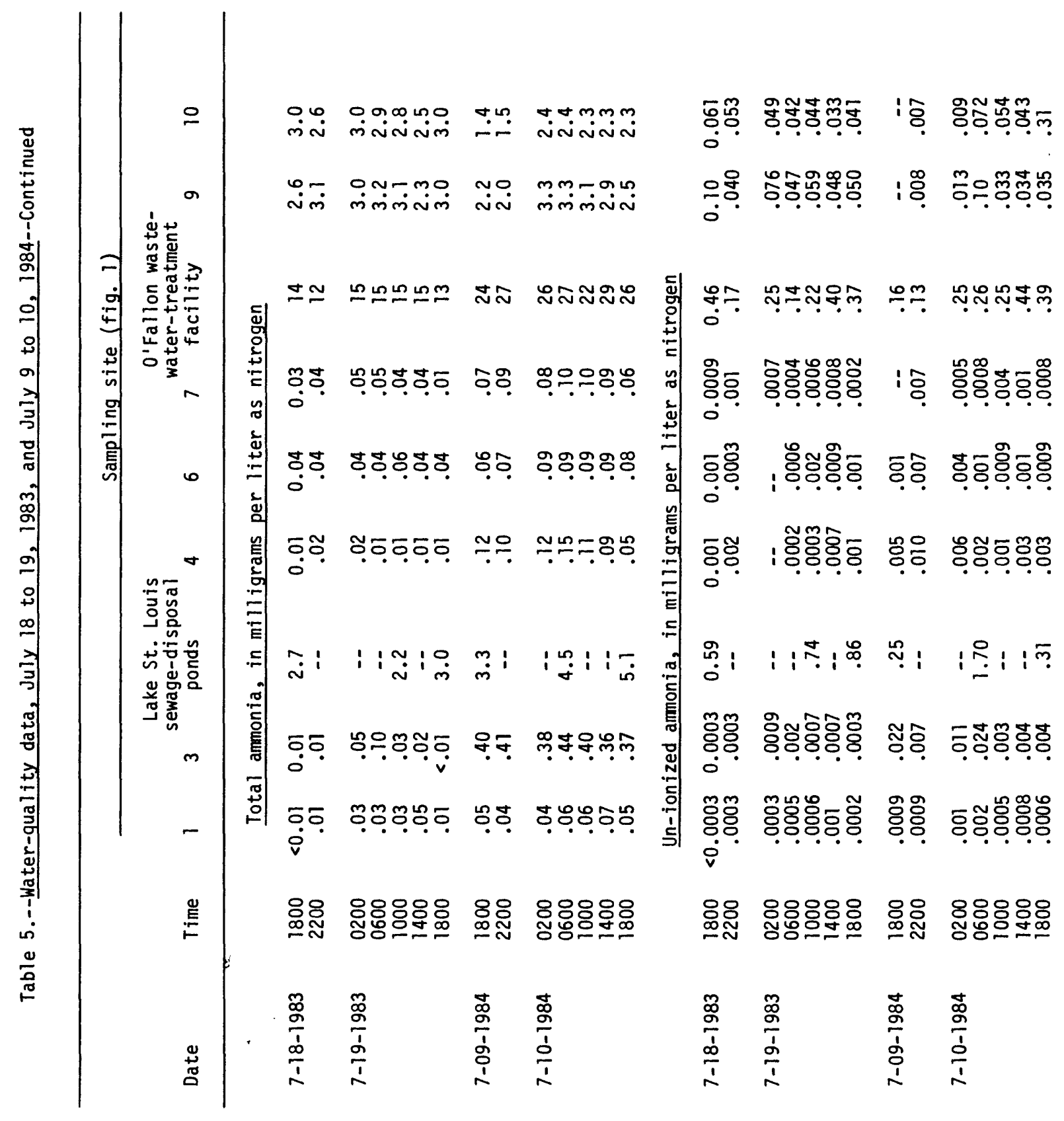




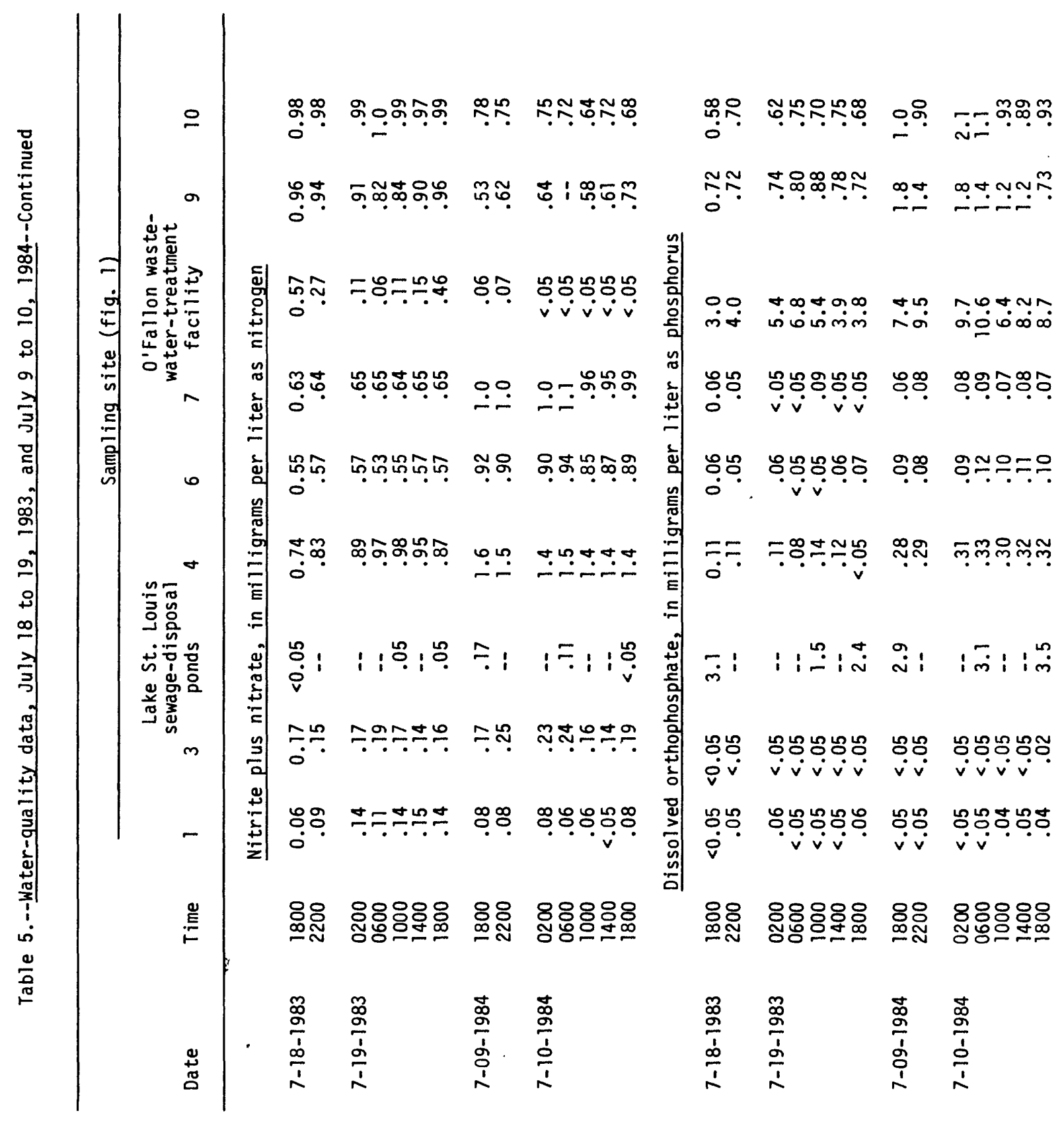




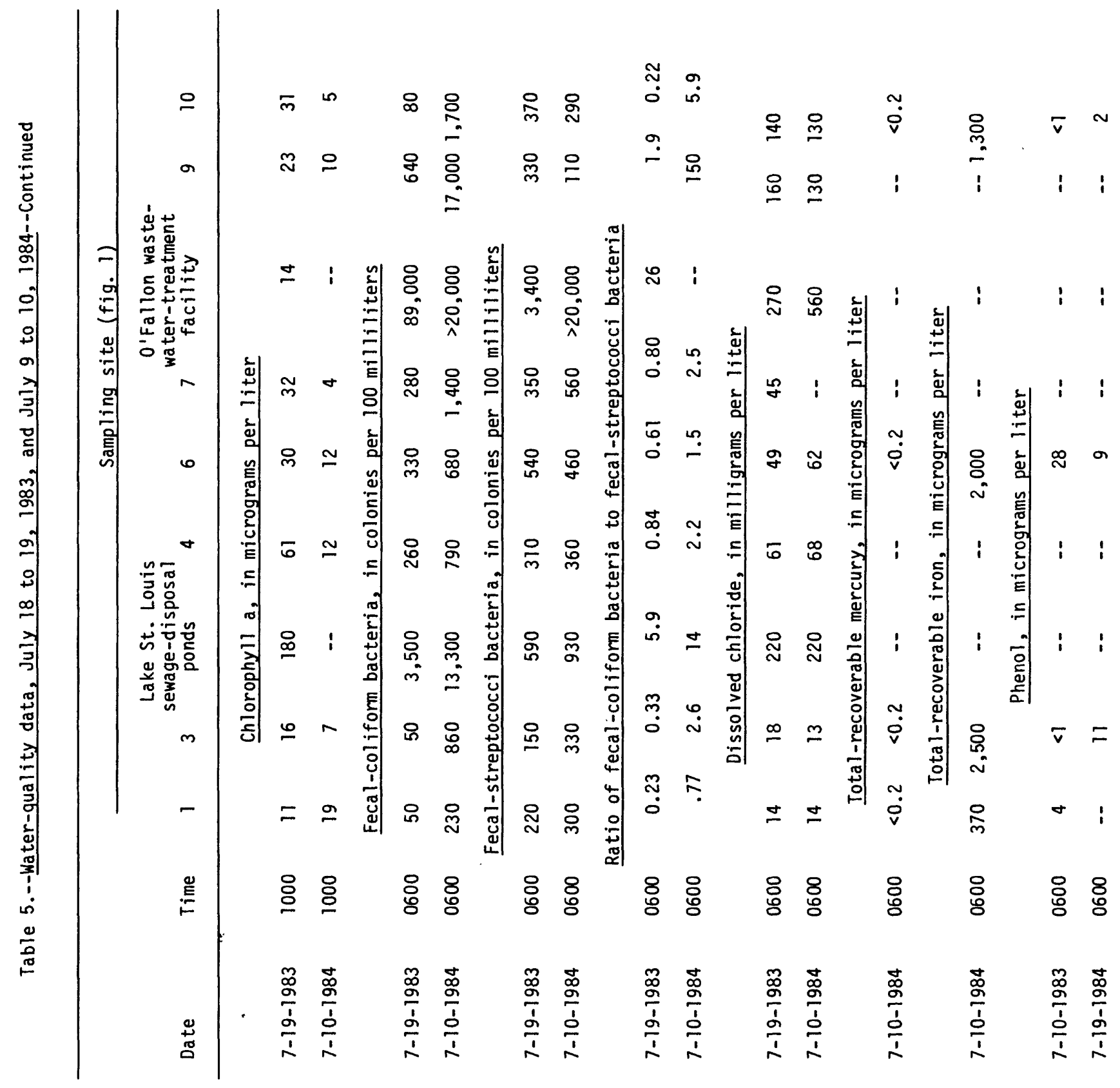




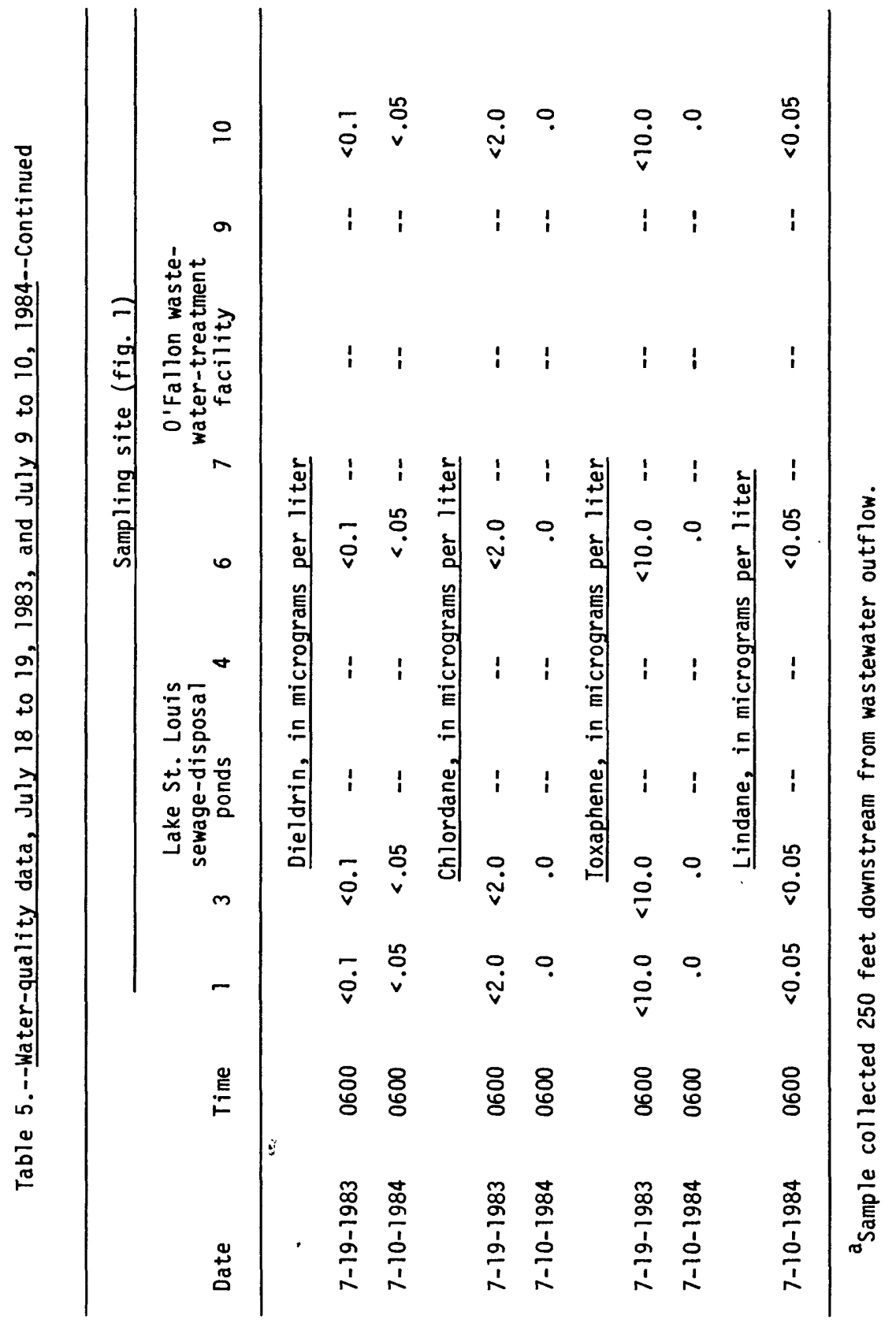




\section{Water Temperature}

Water temperature is a significant property because it affects the metabolic activity of aquatic organisms and water chemistry of streams. The growth rate and metabolic activity of aquatic organisms will increase as the water temperature increases to a certain temperature, beyond which continued increases in temperature will cause decreases in growth rate, and, ultimately, death of aquatic organisms. Dissolved oxygen, which is necessary for benthic respiration, is affected by water temperature; as water temperatures increase, the solubility of oxygen decreases. Water temperature also influences concentration of un-ionized ammonia, which is toxic to fish. As water temperature increases the percentage of un-ionized ammonia increases.

The Missouri water-quality standard for water temperature in Peruque Creek specifies that water contaminants shall not cause water temperatures to be larger than $32.2{ }^{\circ} \mathrm{C}$ or to change more than $2.8{ }^{\circ} \mathrm{C}$ (Missouri Department of Natural Resources, 1984). All measured water temperatures were less than 32.0 ${ }^{\circ} \mathrm{C}$ (table 5). During both sampling periods, the water temperatures of the effluent from the Lake St. Louis sewage-disposal ponds and from the 0'Fallon wastewater-treatment facility were similar to the water temperatures in Peruque Creek.

\section{$\underline{\mathrm{pH}}$}

The $\mathrm{pH}$ value of water is the negative logarithm of the hydrogen-ion activity and ranges from 0 to 14 units. Water with a pH of 7 is considered neutral; a pH less than 7 is considered acidic and a pH larger than 7 is considered alkaline. The $\mathrm{pH}$ value of water affects the chemical reactions taking $\mathrm{place}$, and in turn, chemical reactions that take place can change the $\mathrm{pH}$ value of the water. For example, respiration by living organisms and the decay of organic material produces carbon dioxide $\left(\mathrm{CO}_{2}\right)$ that is converted to carbonic acid $\left[\mathrm{H}_{2} \mathrm{CO}_{3}(\mathrm{aq})\right]$. As the carbonic-acid concentration increases, the $\mathrm{pH}$ value decreases. 'During photosynthesis, carbon dioxide is used, the carbonic acid is converted to carbon dioxide, and the $\mathrm{pH}$ value increases.

The Missouri water-quality standard for $\mathrm{pH}$ in Peruque Creek specifies that water contaminants shall not cause the $\mathrm{pH}$ value to be less than 6.5 or larger than 9.0 (Missouri Department of Natural Resources, 1984). A1l pH values were within this range (table 5).

\section{Specific Conductance}

Specific conductance is a measure of the electrical conductivity of a substance, and it is related to the ionic concentration in the water. As the ionic concentration increases, the electrical conductance increases.

The effluent from the Lake St. Louis sewage-disposal ponds and the 0'Fallon wastewater-treatment facility had larger specific-conductance values than Peruque Creek at the locations of effluent discharge (table 5). As a result, specific-conductance values increased downstream from both wastewater outflows during both sampling periods. 


\section{Dissolved Oxygen}

Dissolved oxygen is essential for all aquatic organisms that respire aerobically. Dissolved oxygen is consumed by bacterial decomposition of organic material in the water and on the streambed, by oxidation of ammonia by nitrifying bacteria, and by respiration of aquatic organisms. Dissolved oxygen is replenished by reaeration and photosynthesis.

Dissolved-oxygen concentration in streams typically has diurnal fluctuations. During daylight periods, photosynthesis may cause the oxygen-producing processes to dominate the oxygen-consuming processes, resulting in an increase in the dissolved-oxygen concentration. During periods of no sunlight, photosynthesis stops and the oxygen-producing processes may be dominated by the oxygen-consuming processes, resulting in a decrease in the dissolved-oxygen concentration.

The Missouri water-quality standard for Peruque Creek specifies that water contaminants shall not cause dissolved-oxygen concentrations to be less than 5.0 milligrams per liter at any time (Missouri Department of Natural Resources, 1984). Dissolved-oxygen concentrations can be less than 5.0 milligrams per liter because of the natural diurnal fluctuations, particularly when water temperatures are warm and dissolved-oxygen solubility is small. This study primarily is concerned with the times when wastewater effluent from the Lake St. Louis sewage-disposal ponds and the O'Fallon wastewater-treatment facility caused the dissolved-oxygen concentrations in Peruque Creek to be smaller than 5.0 milligrams per liter.

Wastewater effluent has the potential for causing small dissolved-oxygen concentrations in the water downstream from the wastewater outflow, because wastewater typically has large concentrations of ammonia and organic material. The ammonia and organic material will oxidize, using the dissolved oxygen in the water. If the reaeration ability is not sufficient, the increased oxygen consumption will decrease the dissolved oxygen in the stream.

At site 1, dissolved-oxygen concentrations were less than the Missouri standard during the 1983 sampling period. This site is upstream from Lake St. Louis and is not affected by any known sources of contamination. The concentration of 4.7 milligrams per liter measured July 19, 1983, was because of a natural diurnal fluctuation.

At site 3, dissolved-oxygen concentrations were less than the Missouri standard during the 1983 and 1984 sampling periods. This site is downstream from Lake St. Louis and upstream from the Lake St. Louis sewage-disposal ponds outflow. Contaminant sources should not be affecting the water quality at this site. The large diurnal fluctuation in dissolved-oxygen concentrations, 4.6 to 16.9 milligrams per liter, and the absence of oxygen-consuming contaminants during the 1983 sampling period indicates that the concentration of 4.6 milligrams per liter measured on July 19, 1983, occurred naturally. During the 1984 sampling period, the diurnal fluctuation of dissolved-oxygen concentrations was small, ranging from 3.6 to 6.9 milligrams per liter. At this time, total-ammonia concentrations, from an unknown source, were larger than those measured in July 1983 and were sufficient to decrease dissolved-oxygen concentrations by ammonia oxidation. 
At site 4, dissolved-oxygen concentrations were less than the Missouri water-quality standard during the 1983 sampling period. Because this site was the closest downstream site to the Lake St. Louis sewage-disposal ponds outflow, the potential for contaminants causing small dissolved-oxygen concentrations would be large. The large diurnal fluctuation in dissolved-oxygen concentrations, from 6.5 to 15.6 milligrams per liter, and the absence of oxygen-consuming contaminants during the 1983 sampling period indicates that the oxygen-consuming contaminants in the wastewater effluent were assimilated within the 5.3 days it took the effluent to reach site 4 . During the 1984 sampling period, the dissolved-oxygen concentration fluctuated diurnally between 4.6 and 10.8 milligrams per liter. The total-ammonia concentrations measured during the 1984 sampling period were slightly larger than those measured during the 1983 sampling period, which indicated that not all the ammonia in the wastewater effluent was oxidized by the time it reached site 4 . Effluent from the Lake St. Louis sewage-disposal ponds probably caused the dissolved-oxygen concentration to be less than the Missouri water-quality standard.

At sites 6 and 7 , dissolved-oxygen concentrations were less than the Missouri standard during both the 1983 and 1984 sampling periods. Dissolved-oxygen concentrations at site 6 fluctuated between 4.8 and 6.1 milligrams per liter during both sampling periods. At site 7 , dissolved-oxygen concentrations fluctuated between 2.3 and 6.6 milligrams per liter during both sampling periods. Indicators of oxygen-consuming potential (total ammonia and carbonaceous biochemical oxygen demand) were detected in small concentrations, so the small dissolved-oxygen concentrations at these two sites were from natural conditions.

At sites 9 and 10, dissolved-oxygen concentrations were less than the Missouri standard during the 1983 and 1984 sampling period. These two sites are downstream from the 0'Fallon wastewater-treatment facility and would be susceptible to contamination by the wastewater effluent. Dissolved-oxygen concentrations at site 9 fluctuated between 0.7 and 2.8 milligrams per liter during both sampling periods. At site 10, dissolved-oxygen concentrations fluctuated between 1.2 and 5.4 milligrams per liter during both sampling periods. The total-ammonia concentrations measured at these two sites were large, which indicated oxygen consumption due to ammonia oxidation also would be large. The large ammonia concentrations at these two sites were caused by the wastewater effluent, which caused the dissolved-oxygen standard to be violated.

\section{Carbonaceous Biochemical Oxygen Demand}

The carbonaceous biochemical oxygen demand (CBOD) is the quantity of oxygen used during the oxidation of carbonaceous organic material by biological processes during a specified period. Although various time periods are used in reporting CBOD, the most common period is 5 days. CBOD is a part of the biochemical oxygen demand (BOD), which includes the quantity of oxygen used by the oxidation of carbonaceous organic material and oxidizable nitrogen. In the determination of CBOD, an inhibitor was added to the sample to prevent the growth of the nitrogenous bacteria that oxidize nitrogen compounds. By eliminating the oxidation of nitrogen compounds, CBOD was determined. 
During the 1983 sampling period the detection limits used by the laboratory in analyzing CBOD concentrations were either 2 or 4 milligrams per liter. Most of the CBOD concentrations in Peruque Creek during this period were less than the detection limits (table 5). During the 1984 sampling period the detection limits were lowered to either 1 or 2 milligrams per liter. Most of the CBOD concentrations in Peruque Creek during this period were less than the detection limits. Determining how Peruque Creek assimilates the carbonaceous orgainc material discharged into the creek from the tow sewage outflows is difficult because of this. More accurate data of the CBOD concentrations in Peruque Creek indicates that $C B O D$ does not have a substantial effect on the dissolved-oxygen concentrations in Peruque Creek.

\section{Chemical 0xygen Demand}

Chemical oxygen demand (COD) is a measure of the oxygen equivalent of organic material that is susceptable to oxidation by a strong chemical oxidant. In the absence of a catalyst, COD determinations fail to include some organic compounds (such as acetic acid) that are available for biological decomposition while including some biologic compounds (such as cellulose) that are not a part of the immediate biochemical oxygen demand (American Public Health Association and others, 1985).

As expected, the largest COD was measured in the effluent from the Lake St. Louis sewage-disposal ponds and the O'Fallon wastewater-treatment facility (table 5). The COD in Peruque Creek was not increased by either of the effluents. One possible explanation is that the additional oxidizable material, discharged into Peruque Creek at the two wastewater outflows, was oxidized by the time it reached the next downstream sampling site.

\section{Streambed Oxygen Demand}

The streambed oxygen demand (SOD) is the quantity of oxygen removed from the overlying water by the oxidation of settled organic material on the streambed. This material can be natural, such as leaves or dead organisms, or produced by humans, such as sludge deposits from sewage effluent. SOD is reported in grams of oxygen consumed per area of streambed per time and was measured using procedures outlined by Terry and others (1983).

Streambed samples were collected from three locations at each sample site. Each sample was put in a plastic container, covered, chilled, sent to the laboratory, and analyzed no more than 24 hours after collection. The samples were analyzed in a respirometer modified from the one described by Nolan and Johnson (1979).

The largest SOD was measured at the Lake St. Louis sewage-disposal ponds (table 5). This was expected because sewage effluent typically has large concentrations of organic material that can settle on the streambed. The smal1 SOD measured at the O'Fallon wastewater-treatment facility was unexpected. This small demand could have resulted from inadequate sampling-site location or inaccuracy in the method. 


\section{Nitrogen}

The most common forms of nitrogen occurring in water are organic nitrogen, ammonia $\left(\mathrm{NH}_{4}^{+}\right)$, nitrite $\left(\mathrm{NO}_{2}^{-}\right)$, and nitrate $\left(\mathrm{NO}_{3}^{-}\right)$. Through the process of nitrification, organic and inorganic nitrogenous compounds from a reduced state are changed to a more oxidized state by biochemical processes (Wetzel, 1975). The generalized nitrification reaction is:

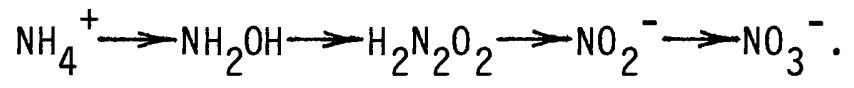

The overall nitrification reaction from ammonia to nitrate is:

$$
\mathrm{NH}_{4}^{+}+2 \mathrm{O}_{2} \rightarrow-\mathrm{NO}_{3}{ }^{-}+\mathrm{H}_{2} \mathrm{O}+2 \mathrm{H}^{+}
$$

which requires 2 moles of oxygen to oxidize 1 mole of ammonia, or requires 4.6 milligrams of oxygen as $\mathrm{O}_{2}$ to oxidize 1 milligram as $\mathrm{N}$ of ammonia to 1 milligram as $\mathrm{N}$ of nitrate.

Total-ammonia concentrations at site 1 indicate background concentrations because no known sources of ammonia were discharging to Peruque Creek upstream from this site. During both sampling periods, total ammonia concentrations ranged from less than 0.01 to 0.07 milligram per liter as $N$ (table 5 ). The oxygen consumption potential from ammonia oxidation would be insignificant as indicted by the small total-ammonia concentrations.

Total-ammonia concentrations at site 3 also should indicate background conditions because it is upstream fom the Lake St. Louis sewage disposal ponds. During the 1984 sampling period, however, total-ammonia concentrations ranged from 0.36 to 0.44 milligram per liter as $N$, which is considerably larger than expected background concentrations. A possible source of the increased total-ammonia concentrations could have been the culvert outflow from Lake St. Louis, but this was not verified. The total-ammonia concentrations measured during the 1984 sampling period were large enough to cause some dissolved-oxygen consumption from ammonia oxidation.

As expected, total-ammonia concentrations in the wastewater effluent from the Lake St. Louis sewage-disposal ponds was large. During both sampling periods, total ammonia concentrations ranged from 2.2 to 5.1 milligrams per liter as N. Because the wastewater effluent contributed such a large quantity of the flow to Peruque Creek, the potential dissolved-oxygen consumption from ammonia oxidation would be large in Peruque Creek downstream from the wastewater effluent.

Most of the ammonia in the effluent form the Lake St. Louis sewage-disposal ponds was oxidized in Peruque Creek by the time it reached site 4, as evidenced by the small total-ammonia concentrations measured during both sampling periods. However, the concentrations measured in 1984 were slightly larger than background concentrations, which indicated that not all of the ammonia from the sewage-disposal ponds had been oxidized. The total-ammonia concentrations during the 1984 sampling period were sufficient to cause some oxygen consumption from ammonia oxidation. 
Total-ammonia concentrations at sites 6 and 7 were at background concentrations during both sampling periods. The oxygen-consumption potential from ammonia oxidation would be insignificant at these two sites.

The total-ammonia concentrations in the effluent from the 0'Fallon wastewater-treatment facility were the largest of those measured during both sampling periods. They ranged from 12 to 27 milligrams per liter as $N$. The oxygen-consumption potential from ammonia oxidation in Peruque Creek downstream from the wastewater outflow would be large.

The total-ammonia concentrations at sites 9 and 10 were much larger than background concentrations. During both sampling periods, the total-ammonia concentrations ranged from 1.4 to 3.3 milligrams per liter. These concentrations indicate that much of the ammonia from the 0'Fallon wastewatertreatment facility was still present, and that the oxygen-consumption potential from ammonia oxidation would be large in Peruque Creek downstream from the wastewater outflow.

When combined with water, ammonia exists in the ionized form $\left(\mathrm{NH}_{4}^{+}\right)$and the un-ionized form $\left(\mathrm{NH}_{3}\right)$. The percentage of ammonia in each form is dependent on water temperature and $\mathrm{pH}$ value. For conditions of low temperature and small values of $\mathrm{pH}$, most of the ammonia is in the ionized form. For conditions of high temperature and large values of $\mathrm{pH}$, most of the ammonia is in the un-ionized form. Thurston and others (1974) give a detailed listing of the percentage of un-ionized ammonia for different temperatures and $\mathrm{pH}$ values.

The quanity of un-ionized ammonia present in water is significant because it is toxic to fish. The Missouri water-quality standard specifies that water contaminates shall not cause un-ionized ammonia concentrations to be larger than 0.1 milligram per liter as $N$ (Missouri Department of Natural Resources, 1984). The un-ionized ammonia standard was exceeded once during both sampling periods on July 10, 1984, when a concentration of 0.31 milligrams per liter as $N$ was calculated (table 5).

Nitrite plus nitrate concentrations increased in Peruque Creek downstream from the wastewater outflow from the Lake St. Louis sewage-disposal ponds and from the 0'Fallon wastewater-treatment facility (table 5) as expected because the ammonia contributed by the wastewater effluent was oxidized to nitrate. Nitrite plus nitrate concentrations were sufficient to create a potential for nuisance aquatic plant growth in Peruque Creek downstream from the wastewater outflows.

\section{Phosphorus}

For many years phosphorus has been credited as the nutrient causing increased aquatic plant growth resulting in eutrophication of streams and lakes. Phosphorus is not the only cause of eutrophication, but it usually is the key element for plant growth that is present in a lesser quantity. The U.S. Environmental Protection Agency (1986) recommends that phosphate concentrations in streams not flowing into lakes be less than 0.1 milligram per liter as $P$ to prevent nuisance growths of aquatic plants and control eutrophication. No water-quality standard for phosphorus has been established for Missouri. 
Most of the phosphorus dissolved in water is in the orthophosphate form. In this form it is readily available as a nutrient for plant and animal growth. Dissolved-orthophosphate concentrations can be depleted from uptake by organisms, adsorption on clay particles, and adsorption on iron-oxides or manganese (Hem, 1985). In Peruque Creek clay particles were prevalent, and total-recoverable iron concentrations were large.

Outflow from the Lake St. Louis sewage-disposal ponds and the O'Fallon wastewater-treatment facility were primary sources of dissolved orthophosphate to Peruque Creek (table 5). During both sampling periods, the dissolvedorthophosphate concentrations downstream from both outflows exceeded the concentration recommended by the U.S. Environmental Protection Agency (1986) with the largest concentrations occurring at sites 9 and 10 . These large dissolved-orthophosphate concentrations indicated a large potential for nuisance aquatic plant growth in Peruque Creek.

\section{Chlorophy11 a}

Chlorophyll a concentrations usually are used as a measure of the phytoplankton biomáss in a stream (U.S. Environmental Portection Agency, 1983b). Phytoplankton is an assemblage of small aquatic plants, such as algae, that are "free floating", possess chlorophyll a, and have photosynthesis as the primary mode of nutrition (Wetzel, 1975). Because of the "free floating" characteristic, phytoplankton populations are largest in areas of little or no stream velocity.

Chlorophyll a concentrations increased downstream from the outflow from the Lake St. Louis sewage-disposal ponds, but not downstream from the outflow from the 0'Fallon wastewater-treatment facility (table 5). Because an abundant supply of nutrients were available and steam velocities were slow, chlorophyll a concentrations were expected to be larger at sites 9 and 10 . A possible explanation is that Peruque Creek is well shaded throughout this reach.

\section{Bacteria}

Fecal-coliform and fecal-streptococci bacteria are normal inhabitants of the large intestine of humans and other mammals. These bacteria are used as indicators of fecal contamination and the possible presence of intestinal microorganisms that may cause disease. These bacteria do not reproduce in a stream environment, so large populations should not occur. Generally, a ratio of fecal-coliform to fecal-streptococci bacteria of 4.0 or more indicates human sources of contamination and a ratio of 1.0 or less indicates livestock sources of contamination (U.S. Environmental Protection Agency, 1978).

The largest bacteria concentrations were measured at the Lake St. Louis sewage-disposal ponds and the 0'Fallon wastewater treatment facility (table 5). During both sampling periods, the number of fecal-coliform-bacteria colonies were more than 4 times than the number of fecal-streptococci-bacteria colonies, which indicates human sources of contamination.

At sites 4, 6, and 7, bacterial concentrations were much less than those from the Lake St. Louis sewage-disposal ponds. Also the ratio was less 4.0 , which indicates that the bacteria from the sewage-disposal ponds died within the 5.3 days it took the effluent to reach site 4 . The large bacterial concentrations measured at sites 4,6 , and 7 were caused by nonpoint sources, probably agricultural. 
Fecal-coliform-bacteria concentrations decreased between sites 9 and 10 during both sampling periods. This decrease indicated that the population of fecal-coliform-bacteria from the 0'Fallon wastewater-treatment facility was dying in Peruque Creek. Fecal-streptococci-bacteria concentrations slightly increased between sites 9 and 10 during both sampling periods, probably from agricultural activity along Peruque Creek.

\section{Dissolved Chloride}

Dissolved-chloride concentrations measured during both sampling periods increased downstream from the Lake St. Louis sewage-disposal ponds and the o'Fallon wastewater-treatment facility (table 5), because of the large dissolved-chloride concentrations in both wastewater effluents. Dissolved-chloride concentrations in Peruque Creek ranged from 13 to 160 milligrams per liter.

\section{Total-Recoverable Mercury}

The Missouri water-quality standard for mercury specifies that water contaminants shall not cause the toxic form of mercury to be larger than 2 micrograms per liter (Missouri Department of Natural Resources, 1984). A11 total-recoverable mercury concentrations were less than the laboratory detection limit of 0.2 microgram per liter (table 5 ).

\section{Total-Recoverable Iron}

The Missouri water-quality standard specifies that water contaminants shall not cause the toxic form of iron to exceed 1,000 micrograms per 1iter (Missouri Department of Natural Resources, 1984). Uncertainity exists about the toxic form, but it is considered to be between the total and the dissolved concentration. The total-recoverable concentration was intended to best approximate the toxic concentration, but the possibility exists that the extraction technique may be too strong, and concentrations larger than the toxic form may result (John Lodderhose, Missouri Department of Natural Resources, oral commun., 1984). For this study, only total-recoverable iron was measured.

Total-recoverable iron increased from 370 to 2,500 micrograms per 1iter between sites 1 to site 3, then decreased to 2,000 micrograms per 1 iter at site 6 and decreased further to 1,300 micrograms per liter at site 10 . This indicates that the outflow from Lake St. Louis may be responsible for the large total-recoverable iron concentrations in Peruque Creek.

\section{Phenol}

Phenol is an aromatic carbon compound that is toxic to freshwater fish. The Missouri water-quality standard states that water contaminants shall not cause phenol concentrations to exceed 100 micrograms per liter (Missouri Department of Natural Resources, 1984). Phenol concentrations measured during both sampling periods were less than the standard (table 5). 
Pesticides

The pesticides sampled in this study were dieldrin, chlordane, toxaphene, and lindane. The Missouri water-quality standard states that these pesticides should not be present in Peruque Creek (Missouri Department of Natural Resources, 1984). All concentrations were less than the detection limit for each individual pesticide (table 5).

\section{NON-UNIFORM CONDITIONS}

During water-quality assessment studies, the identification of non-uniform hydraulic and water-quality conditions can be significant. Non-uniform conditions could cause difficulties in modeling the flow regime and in obtaining representative water-quality samples. Non-uniform inputs of water-quality consituents into the stream could cause difficulties in comparing water-quality properties and constituents collected at different locations in the stream.

\section{Hydraulic}

Many hydraulic and water-quality models have been developed using the theory of one-dimensional flow. One-dimensional flow occurs when the velocity across a stream cross-sectional width and depth are equal (fig. 2). With this type of flow, complete mixing has occurred in the cross section; therefore, a water-quality sample collected from the right bank would be identical to a sample collected from the left bank. One-dimensional flow is used in modeling because the water and quality of water can be routed downstream as blocks.

However, streamflow is never one-dimensional. Frictional losses between the streambed and water interface decrease stream velocities and cause rapid velocities to occur in the center of the stream and slow velocities to occur near the streambed and water interface (fig. 3). In some streams the velocity is rapid enough to render the frictional losses insignificant and flow in the stream resembles one-dimensional flow. When the stream velocity is slow, such as in Peruque Creek, the frictional losses may cause areas of no water movement along the edges. This type of stream is inadequately mixed and the water quality may vary along the channel cross section.

Slow velocities and areas of no water movement have a significant effect on the dispersion characteristics of Peruque Creek. Water can be stored in areas of no water movement and later released to the mainstem flow. For example, when dye was injected into Peruque Creek, it was observed in areas of no water movement and later was dispersed into the moving water, which resulted in extending the dye concentration versus time curve (fig. 4). Thus the peak dye concentration arrived at the sampling station much sooner than the centroid of the dye mass. A sluge-type-waste spill in Peruque Creek would be dispersed in a similar manner.

Because of inadequate mixing, considerable care was required in locating sampling sites and in obtaining representative samples. Samples were collected using a depth-integrated method, which involved compositing samples from many locations in a stream cross section. 


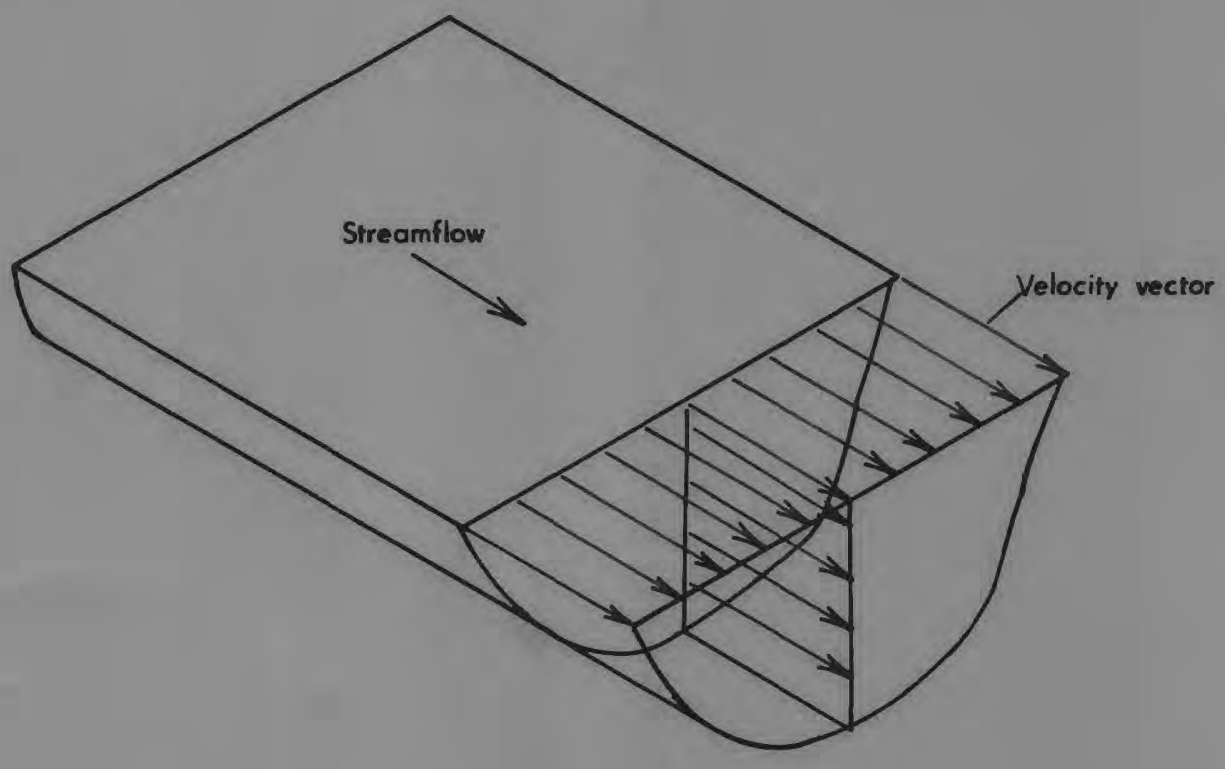

Figure 2.--One-dimensional flow showing equal velocity through a stream cross section.

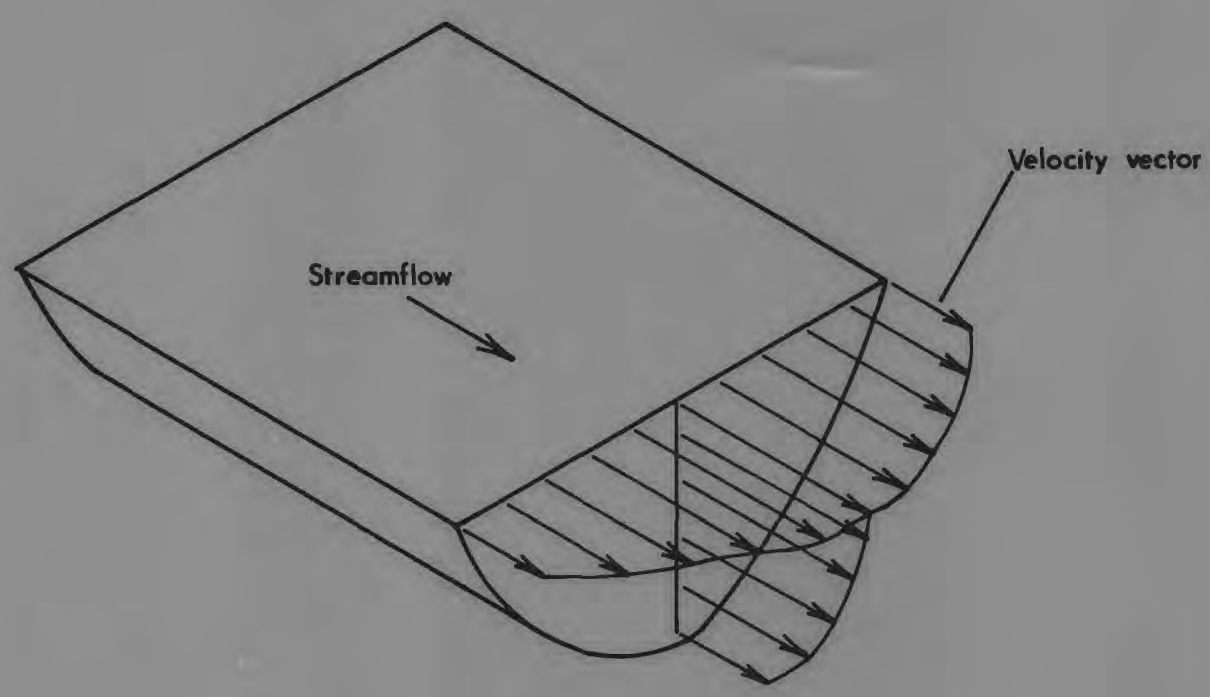

Figure 3.--Velocity profile in a typical stream cross section. 


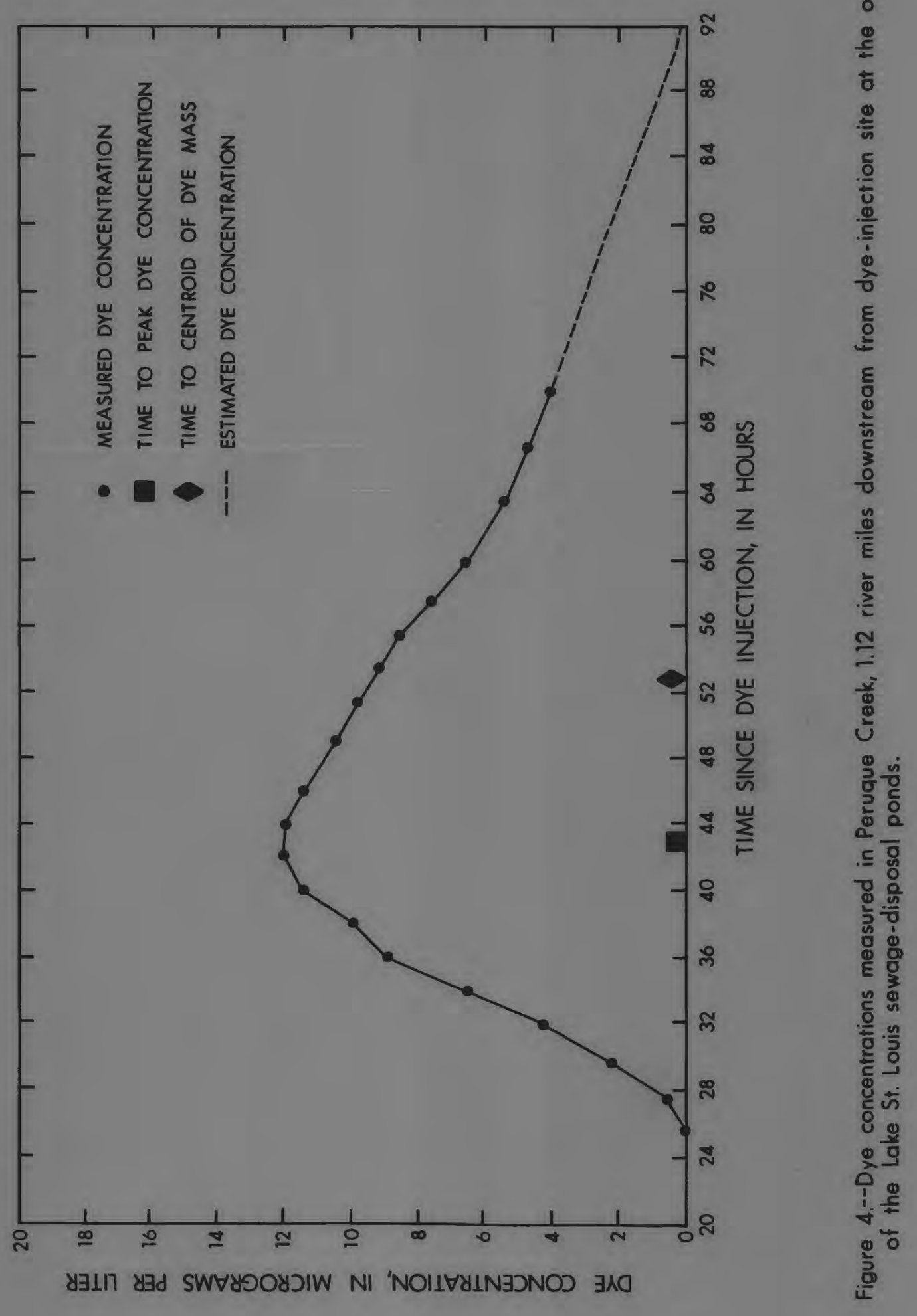


Water Quality

Steady-state conditions are needed for a water-quality assessment when comparing property values and constituent concentrations obtained from selected locations in a stream reach. Steady state implies that the quantity and quality of water entering the stream system is constant for the period of time it takes the water to travel through the study reach. Because the residence time of the sewage at the Lake St. Louis sewage-disposal ponds is long, the quality of the effluent is not expected to vary considerably with time; therefore, steady-state conditions are expected from this source. However, the residence time of the effluent at the O'Fallon wastewater-treatment facility is shorter and the effluent quality can change daily. Because of these conditions, the possibility exists that Peruque Creek was not under steady-state conditions during both sampling periods.

Steady-state conditions were evaluated by comparing calculated total loads of nitrogen for both sampling periods (table 6). If steady-state conditions exist, then the sum of nitrgoen loads at site 7 and the 0'Fallon wastewater treatment facility should be about the same as the nitrogen loads at sites 9 or 10. During the 1983 sampling period, the nitrogen load at site 10 was smaller than the load at site 9 because of decreased flow at site 10 resulting from irrigation pumpage. The sum of the nitrogen loads at site 7 and the 0 'Fallon wastewater-treatment facility was about the same as the nitrogen load at site 9, indicating that steady-state conditions existed during the 1983 sampling period. During the 1984 sampling period, the sum of the nitrogen loads at site 7 and the 0'Falion wastewater-treatment facility was about four times larger than the nitrogen loads at sites 9 or 10, which indicated steady-state conditions did not exist in Peruque Creek during the 1984 sampling period.

\section{WATER-QUALITY MODEL}

Originally, one of the objectives of this study was to model the water quality in Peruque Creek by using the QUAL-II/SEMCOG model and then simulate the effects of future wastewater discharges from the 0'Fallon wastewater-treatment facility. However, the water-quality model could not be adequately calibrated or verified. The reasons are explained in this section, along with a brief description of the model.

The QUAL-II/SEMCOG water-quality model was developed by Water Resources Engineers, Inc., for the Southeast Michigan Council of Governments. Details of the model formulation and operation are documented by Roesner and others (1981). The model is based on the assumption that the stream is well- mixed and the major transport mechanisms, advection and dispersion, are substantial only along the main direction of flow. The model allows for multiple waste discharges, tributary inflows, and ground-water inflow or outflow.

The QUAL-II/SEMCOG model approximates a stream reach by defining it as a series of subreaches. The channel configuration, hydraulic characteristics, decay rates, and reaction rates are constant in each subreach. The constituent concentrations that the model simulates are input at headwater and point-source locations. These constituents are routed downstream through each subreach where the constituent concentrations are changed according to the decay and reaction rates. The constituents simulated are dissolved oxygen, 5-day CBOD, total ammonia, total nitrate, and algae as chloropyll a. The model is used in a 
Table 6.--Computations of nitrogen loads at selected sampling sites, JuTy 18 to 19,1983 , and July 9 to 10,1984

$[--$, data not collected or computed]

\begin{tabular}{|c|c|c|c|c|}
\hline $\begin{array}{c}\text { Sampling-site } \\
\text { number or location } \\
\text { (fig. 1) }\end{array}$ & $\begin{array}{l}\text { Discharge, } \\
\text { in cubic } \\
\text { feet per } \\
\text { second }\end{array}$ & $\begin{array}{c}\text { Total } \\
\text { ammonia, } \\
\text { in milligrams } \\
\text { per liter } \\
\text { as } \\
\text { nitrogen }\end{array}$ & $\begin{array}{l}\text { Nitrite } \\
\text { plus nitrate, } \\
\text { in milligrams } \\
\text { per liter } \\
\text { as } \\
\text { nitrogen }\end{array}$ & $\begin{array}{c}\text { Nitrogen load } \\
\text { (total ammonia } \\
\text { and nitrite } \\
\text { plus nitrate) } \\
\text { in grams } \\
\text { as, } \\
\text { nitrogen } \\
\text { per second }\end{array}$ \\
\hline \multicolumn{5}{|c|}{ July 18 to 19,1983} \\
\hline $\begin{array}{l}7 \\
0^{\prime} \text { Fallon wastewater- } \\
\text { treatment facility } \\
7 \text { and } 0 \text { 'Fallon } \\
\text { wastewater-treatment } \\
\text { facility } \\
9 \\
10\end{array}$ & $\begin{array}{c}3.37 \\
\\
1.34 \\
\\
\\
\\
4.71 \\
4.70 \\
\text { (estimated) } \\
2.89\end{array}$ & $\begin{array}{l}-- \\
2.9 \\
2.8\end{array}$ & .90 & $\begin{array}{l}.60 \\
.51 \\
.31\end{array}$ \\
\hline \multicolumn{5}{|c|}{ July 9 to 10,1984} \\
\hline $\begin{array}{l}7 \\
\text { 0'Fallon wastewater- } \\
\text { treatment facility } \\
7 \text { and } 0 \text { 'Fallon } \\
\text { wastewater-treatment } \\
\text { facility } \\
9 \\
10\end{array}$ & $\begin{array}{l}3.43 \\
3.29 \\
\\
\\
6.72 \\
6.70 \\
6.70 \\
\text { (estimated) }\end{array}$ & $\begin{array}{r}-- \\
2.8 \\
2.1\end{array}$ & $\begin{array}{l}-- \\
.62 \\
.72\end{array}$ & $\begin{array}{r}2.54 \\
.65 \\
.64\end{array}$ \\
\hline
\end{tabular}


steady-state mode with constant water temperature. With constant-input concentrations, the system will reach equilibrium, and a concentration profile through the modeled reach is produced for each constituent.

\section{Calibration}

Calibration of the model is done by determining the decay rates and reaction rates needed in each subreach to simulate each constituent. The procedures used to determine these rates are described in Roesner and others (1981) and U.S. Environmental Protection Agency (1983a; 1983b). The values were determined from the 1983 data and are listed in table 7. The discharge and concentration of the water-quality constituents input at the headwater and point-source locations are listed in table 8 and are the average concentrations measured during July 18 to 19, 1983. Total nitrate was not measured during the study, but the author assumed that the nitrite component of the measured nitrite plus nitrate concentrations would be negligible.

The principal test to determine if the calibration is acceptable is the comparison of the measured and computed dissolved-oxygen concentrations (fig. $5)$. The model underpredicted the measured dissolved-oxygen concentration at site 4 , probably because the model did not completely account for oxygen produced by photosynthesis.

At sites 9 and 10 the model overpredicted the measured dissolved-oxygen concentrations. During the calibration process it was determined that the model could simulate the dissolved-oxygen concentrations if a larger ammonia decay rate was used to create a larger demand on the dissolved oxygen. The ammonia simulation (fig. 6) indicates that a larger ammonia decay rate could not be used and still adequately predict measured ammonia concentrations. The simulated dissolved-oxygen concentrations could be more similar to the measured concentrations through manipulating the reaeration coefficient and the SOD. Because both parameters were measured, this manipulation could not be justified. The discrepancy between measure and simulated dissolved-oxygen concentrations at sites 9 and 10 indicates that processes affecting the water quality in Peruque Creek are more complex than the simple mathematical relations used in the model.

\section{Verification}

Although the calibration of dissolved oxygen was considered marginal, verification was attempted using a different data set. The data collected in 1984 were used with the decay and reaction rates determined during calibration.

The model adequately simulated the dissolved-oxygen concentrations upstream from site 7 (fig. 7). Downstream from site 7 , the simulated dissolved-oxygen concentration became zero, but the measured concentrations at sites 9 and 10 ranged from about 0.5 to about 5.0 milligrams per liter. The simulated dissolved-oxygen concentration of zero was caused by large 5-day CBOD and total-ammonia loads from the 0 'Fallon wastewater-treatment facility, as shown in figures 8 and 9. Peruque Creek did not meet steady-state conditions because the 0 'Fallon wastewater-treatment facility was discharging effluent of different quality during the sampling period than it was at least 2 days earlier. This explains why the simulated 5-day CBOD and total-ammonia concentrations were much larger than the measured concentrations at sites 9 and 10 , and also why the simulated dissolved-oxygen concentrations were much smaller than the measured concentrations. 


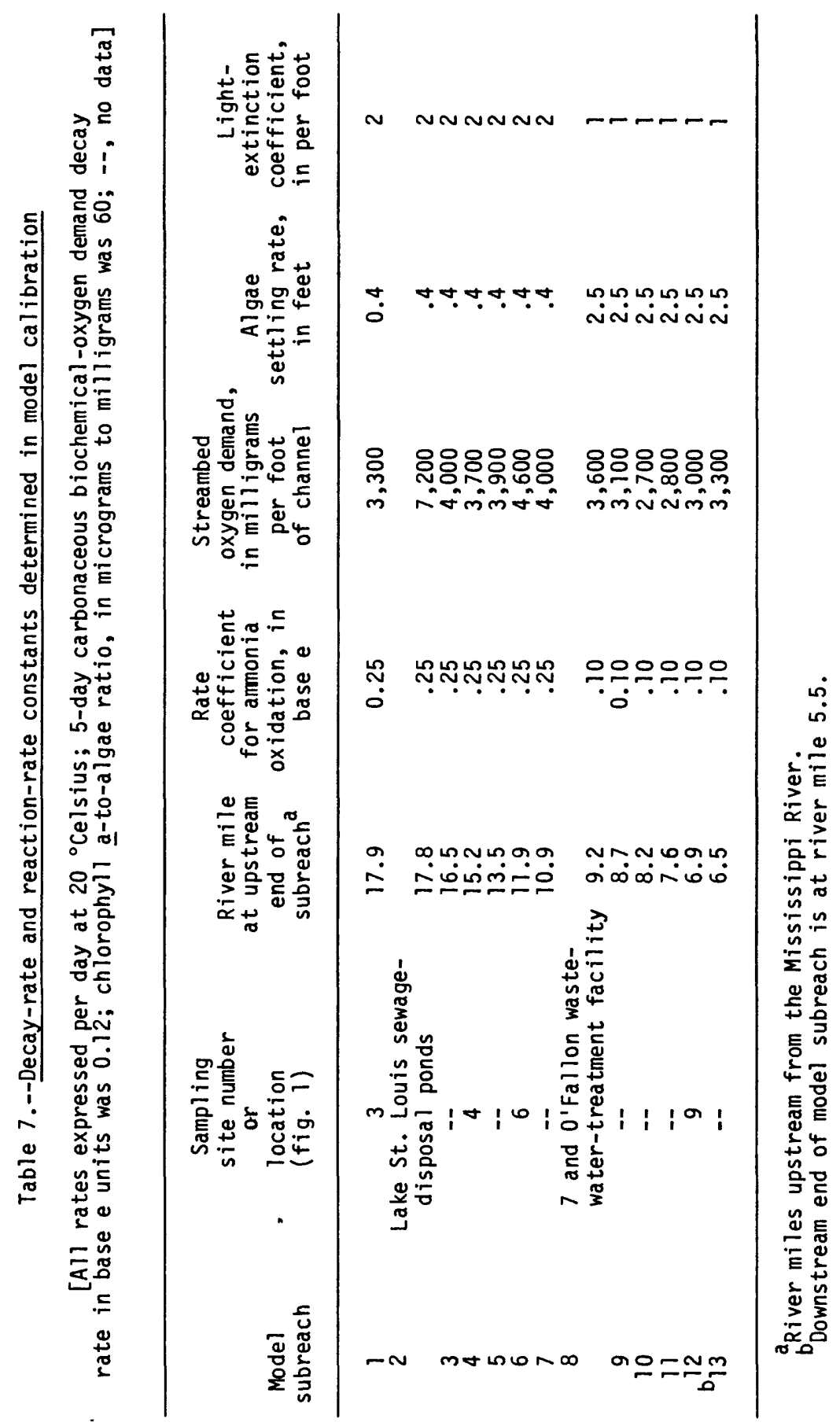




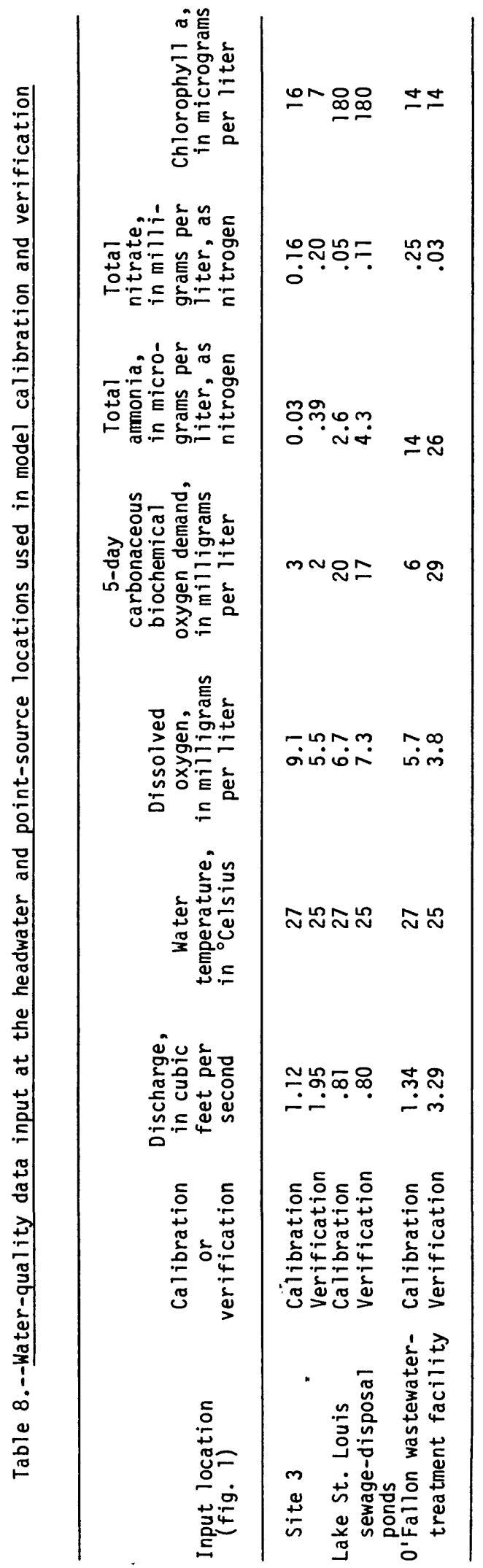




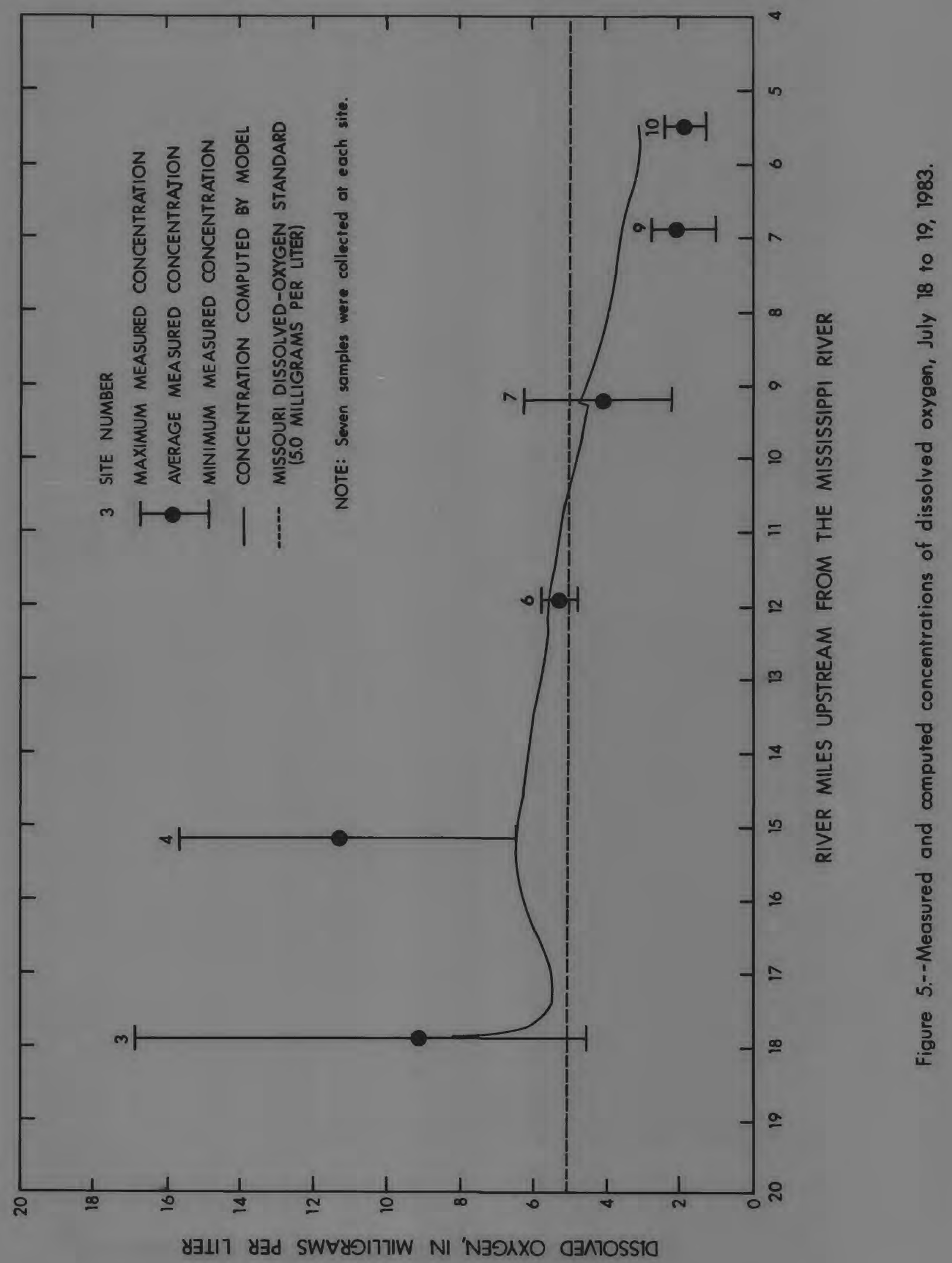




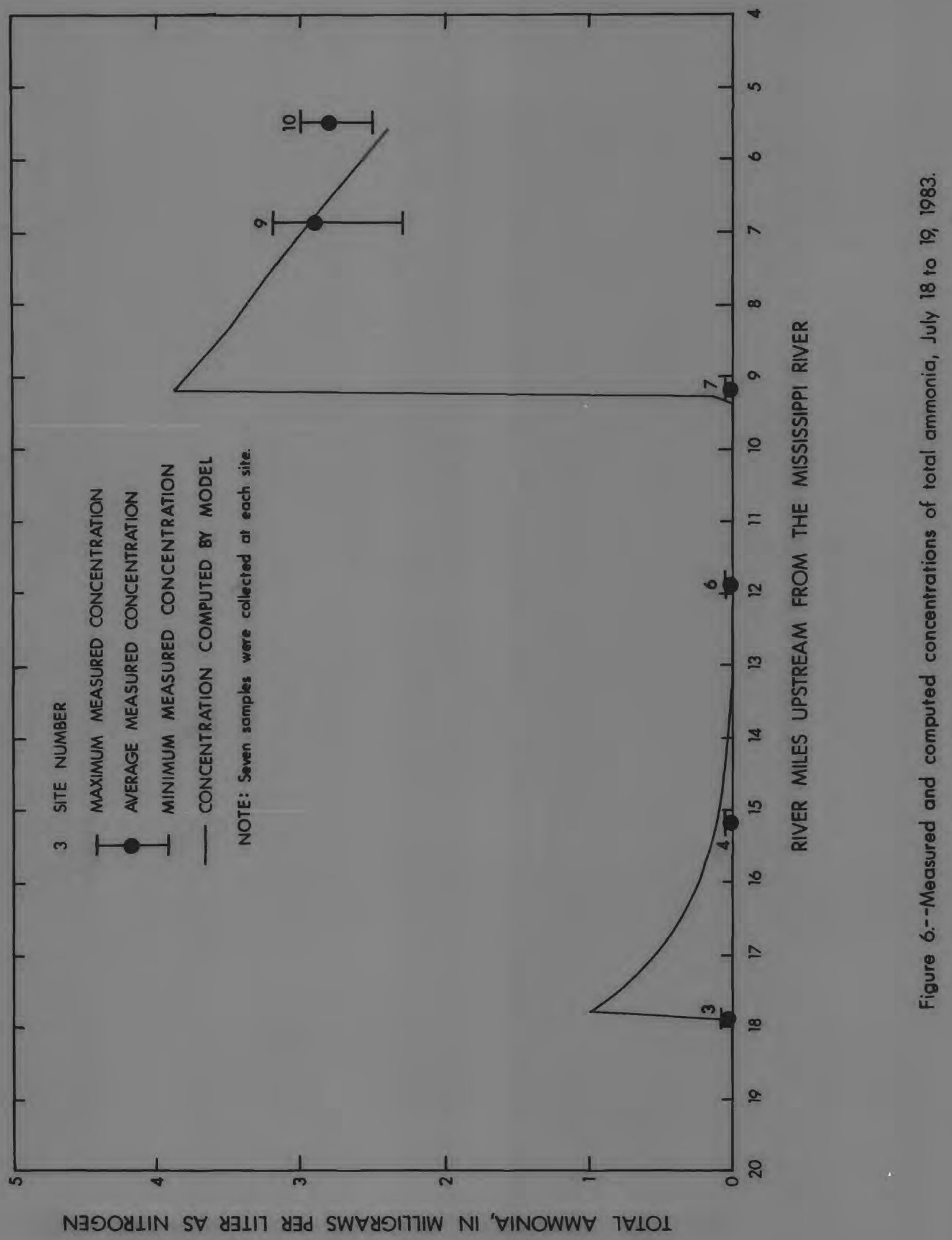




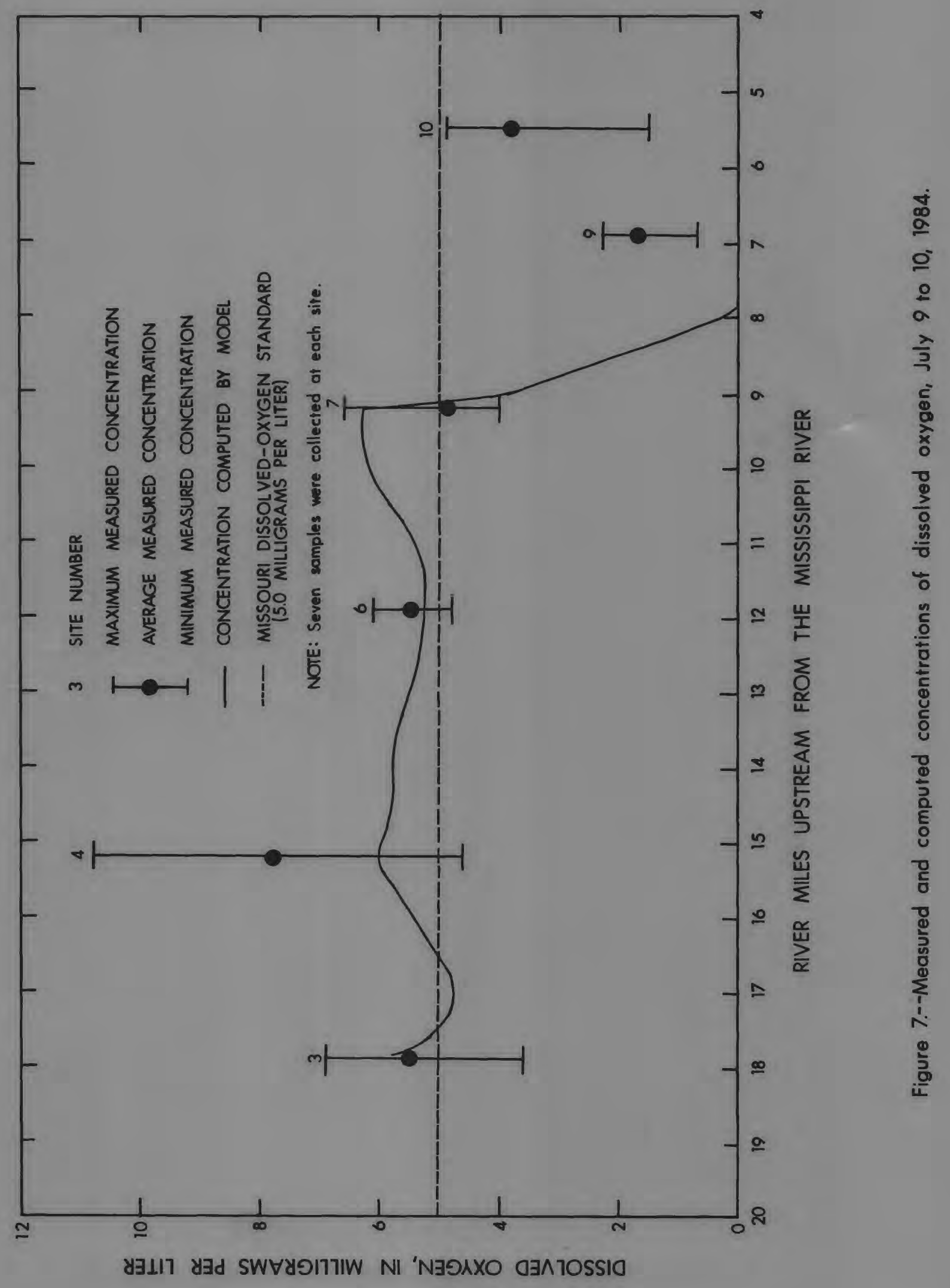




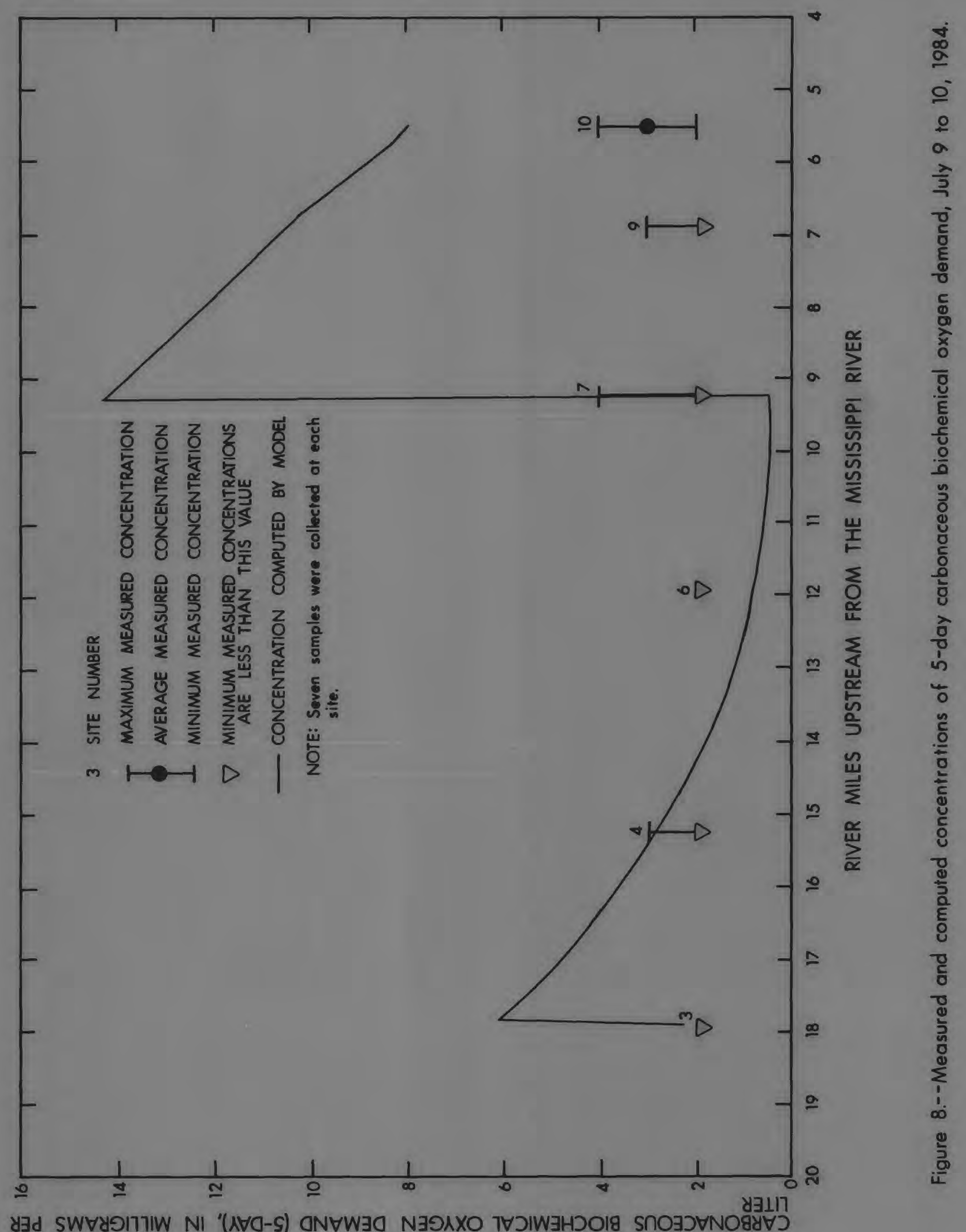




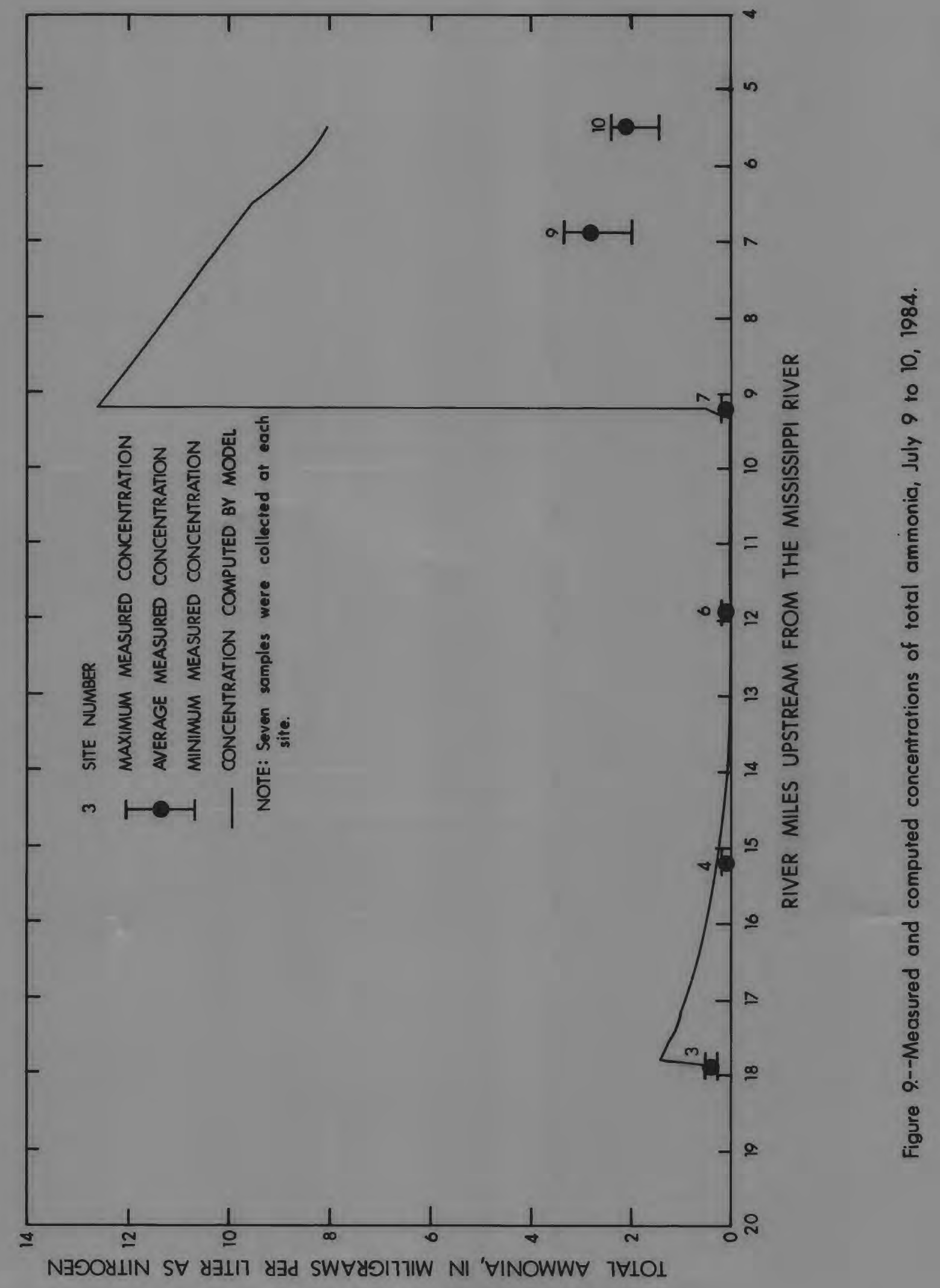


The water-quality model of Peruque Creek was based on the assumption that the creek system was in a one-dimensional and steady-state condition. The slow velocities and generally inadequate mixing conditions caused by the long, deep-pool channel geometry indicates that flow in Peruque Creek does not conform to one-dimensional flow patterns and does not meet steady-state conditions. For these reasons the model could not be verified.

If the calibration had been more accurate and the model had been verified, the model could have been used to evaluate the degree of wastewater treatment necessary to ensure that wastewater effluent would not cause the dissolvedoxygen concentration to be less than the water-quality standard. The calibration and verification exercises were useful, however, in that they revealed that the waste-load assimilative capacity of Peruque Creek is limited during low-flow conditions. This is indicated in figure 5 where measured and simulated dissolved-oxygen concentrations are much less than the standard of 5.0 milligrams per liter.

\section{SUMMARY}

Physical, chemical, and biological data collected along the downstream 24.1-river-mile reach of Peruque Creek from July 18 to 19, 1983, and July 9 to 10, 1984, were used to characterize the water-quality conditions in the creek. Two wastewater sources discharge into this reach of Peruque Creek: the Lake St. Louis sewage-disposal ponds and the 0'Fallon wastewater-treatment facility.

The Lake St. Louis sewage-disposal ponds discharge into Peruque Creek 17.8 river miles upstream from the Mississippi River. During both sampling periods, average effluent discharge was about 0.8 cubic foot per second, which was about 42 percent of the flow in the creek in the 1984 sampling period. During both sampling periods, it took the effluent 17 to 18 days to travel the 12.3 river miles to site 10 .

The 0'Fallon wastewater-treatment facility discharges into Peruque Creek 9.2 river miles upstream from the Mississippi River. During the 1983 sampling period, the average effluent discharge was 1.34 cubic feet per second, which was about 29 percent of the flow in the creek. It took the effluent 3.4 days to travel the 3.7 river miles to site 10 . During the 1984 sampling period the average effluent discharge was 3.29 cubic feet per second, which was about 49 percent of the flow in the creek. It took this effluent 4.4 days to travel to site 10 .

Dissolved-oxygen concentrations less than the water-quality standard of 5.0 milligrams per liter for Peruque Creek were measured at each sampling site in the 1983 and 1984 sampling periods. The effluent from the Lake St. Louis sewage-disposal ponds was not credited with causing this violation of the standard because oxygen-consuming materials traceable to the effluent, such as 5-day CBOD, or total ammonia were not measured in sufficient quantities. However, the effluent from the 0'Fallon wastewater-treatment facility caused the dissolved oxygen to be less than the water-quality standard downstream from the outflow at sites 9 and 10 . 
During both sampling periods, total-ammonia concentrations did not increase downstream from the Lake St. Louis sewage-disposal ponds at site 4, but they increased downstream from the $0^{\prime}$ Fallon wastewater-treatment facility at sites 9 and 10. The 5.3-day traveltime from the sewage-disposal ponds to site 4 was sufficient time to allow the total ammonia from the ponds to be oxidized before it reached site 4 . Large total-ammonia concentrations and the estimated 2- to 4.4-day traveltime from the 0 'Fallon wastewater-treatment facility to sites 9 and 10 caused only part of the the total ammonia to oxidize. The large totalammonia concentration at site 10 caused the un-ionized ammonia standard of 0.1 milligram per liter to be exceeded once during both sampling periods.

Attempts were made to calibrate and verify the QUAL-II/SEMCOG version water-quality model. The calibration of the model was considered inadequate and verification not possible. The slow velocities and generally inadequate mixing in the long, deep-pool channel indicated that flow in Peruque Creek did not conform to one-dimensional flow patterns. Analys is of nitrogen loads from the $0^{\prime}$ Fallon wastewater-treatment facility and at sites 9 and 10 indicated that steady-state conditions did not exist in Peruque Creek during the 1984 sampling period. Although the model could not be calibrated and verified, it indicated that during low-flow conditions the wasteload-assimilative capacity of Peruque Creek was limited. 


\section{REFERENCES}

Allgood, F.P., and Persinger, I.D., 1979, Missouri general soil map and soil association descriptions: U.S. Department of Agriculture, Soil Conservation Service, $74 \mathrm{p}$.

American Public Health Association, American Water Works Association, and Water Pollution Control Federation, 1985, Standard methods for the examination of water and wastewater (16th ed.): New York, American Public Health Association, Inc., $1268 \mathrm{p}$.

Bansa1, M.K., 1983, Atmospheric reaeration in natural streams: Water Research, v. 7 , no. 5, p. 764-782.

Bennett, J.P., and Rathbun, R.E., 1972, Reaeration in open-channel flow: U.S. Geological Survey Professional Paper 737, 75 p.

Cadwaller, T.E., and McDonnel1, A.J., 1969, A multivariate analys is of reaeration data: Water Research, v. 3, p. 731-742.

Churchill, M.A., Elmore, H.L., and Buckingham, R.A., 1962, The prediction of stream reaeration rates: Journal of the Sanitary Engineering Division, American Society of Civil Engineers, v. 88, no. SA-4, Proceedings Paper 3199 , p. 1-46.

East-West Gateway Coordinating Council, $\mathrm{CM}_{2}-\mathrm{Hill}$, Zurheidehermann, and Team Four, Inc., 1977, Areawide waste treatment management study (208): St. Charles, Missouri, St. Charles County Workshop, $210 \mathrm{p}$.

Hem, J.D., 1985, Study and interpretation of the chemical characteristics of natural water (3rd ed.): U.S. Geological Survey. Water-Supply Paper $2254,263 \mathrm{p}$.

Langbein, W.B., and Durum, W.H., 1967, The aeration capacity of streams: U.S. Geological Survey Circular 542, $6 \mathrm{p}$.

Missouri Department of Natural Resources, 1976, Water quality management plan for upper Mississippi-Salt River basin: Jefferson City, Missouri Division of Environmental Quality, in accordance with Section 303(e) of Public Law 92-500 Water Quality Program, $268 \mathrm{p}$.

1984, Missouri water quality standards--Chapter 7, water quality: Jefferson City, Clean Water Commission, $55 \mathrm{p}$.

Negulescu, M., and Rojanski, V., 1969, Recent research to determine reaeration coefficient: Water Research, v. 3, no. 3, p. 184-202.

Nolan, D.M., and Johnson, A.F., 1979, A method for measuring sediment-oxygen demand using a bench model benthic respirometer: U.S. Environmental Protection Agency, $5 \mathrm{p}$.

0'Connor, D.J., and Dobbins, W.E., 1958, Mechanisms of reaeration in natural streams: American Society of Civil Engineers Transactions, v. 123, p. $641-684$. 
Owens, M., Edwards, R.W., and Gibbs, J.W., 1964, Some reaeration studies in streams: International Journal of Air and Water Pollution, v. 8, no. 819, p. 469-486.

Padden, T.J., and Gloyna, E.F., 1971, Simulation of stream processes in a model river: Austin, University of Texas, Center for Research in Water Resources, Report No. EHE-70-23, CR WR-72, Technical Report 2, 130 p.

Rathbun, R.E., 1977, Reaeration coefficients of streams--State-of-the-art: American Society of Civil Engineers, Journal of the Hydraulics Division, v. 103, no. NY-4, p. 409-424.

Rathbun, R.E., Shultz, D.J., and Stephens, D.W., 1975, Preliminary experiments with a modified tracer technique for measuring stream reaeration coefficients: U.S. Geological Survey Open-File Report 75-256, $36 \mathrm{p}$.

Roesner, L.A., Giguere, P.R., and Evenson, D.E., 1981, Computer program documentation for the stream quality mode1 QUAL-II: U.S. Environmental Protection Agency, EPA 600/9-81-014, 225 p.

Sverdrup and Parcel and Associates, 1984, 201 facilities plan for the Duckett Creek area: St. Louis, $133 \mathrm{p}$.

Terry, J.E., Morris, E.E., and Bryant, C.T., 1983, Water-quality assessment of White River between Lake Sequoyah and Beaver Reservoir, Washington County, Arkansas: U.S. Geological Survey Water-Resources Investigations Report 82-4063, 84 p.

Thurston, R.V., Russo, R.C., and Emerson, Kenneth, 1974, Aqueous ammonia equilibrium calculations: Bozeman, Montana State University, Fisheries Biossay Laboratory Technical Report 74-1, $18 \mathrm{p}$.

U.S. Department of Commerce, 1983, 1980 census of population: Washington, D.C., Bureau of the Census, 269 p., 4 appendices.

U.S. Environmental Protection Agency, 1978, Microbiological methods for monitoring the environment, water, and wastes: Washington, D.C. 338 p.

U.S. Environmental Protection Agency, 1983a, Technical guidance manual for performing waste load allocations, Book II, Streams and Rivers, Chapter 1: Washington, D.C., Office of Water Regulation and Standards, $253 \mathrm{p}$.

1983b, Technical guidance manual for performing waste load allocations, Book II, Streams and Rivers, Chapter 2: Washington, D.C., Office of Water Regulation and Standards, $126 \mathrm{p}$.

1986, Quality criteria for water: Washington, D.C., EPA 440/5-86-001, $401 \mathrm{p}$.

Wetzel, R.G., 1975, Limnology: Philadelphia, W.B. Saunders Co., 743 p.

Wilson, J.F., Jr., 1968, Fluorometric procedures for dye tracing: U.S. Geological Survey Techniques of Water-Resources Investigations, Book 3, Chapter $\mathrm{A} 12,31 \mathrm{p}$. 